NBER WORKING PAPER SERIES

\title{
HEALTH PLAN CONVERSIONS: ARE THEY IN THE PUBLIC INTEREST?
}

Nancy Dean Beaulieu

Working Paper 10127

http://www.nber.org/papers/w10127

\author{
NATIONAL BUREAU OF ECONOMIC RESEARCH \\ 1050 Massachusetts Avenue \\ Cambridge, MA 02138 \\ December 2003
}

An earlier version of this paper was presented at the NBER 2003 Frontiers in Health Policy Research Conference that took place in Washington D.C. in June 2003. The research for this paper was funded in part by the D.C. Appleseed Center for Law and Justice, a public advocacy organization that became a formal party to the official conversion proceedings of the Blue Cross and Blue Shield plan, CareFirst Inc. I am grateful to Richard Herzog, Walter Smith, Richard Meyer, Jack Needleman, and participants in the NBER 2003 Frontiers in Health Policy Research Conference for helpful comments and conversations. The views expressed herein are those of the authors and not necessarily those of the National Bureau of Economic Research.

C2003 by Nancy Dean Beaulieu. All rights reserved. Short sections of text, not to exceed two paragraphs, may be quoted without explicit permission provided that full credit, including $\mathbb{C}$ notice, is given to the source. 
Health Plan Conversions: Are They in the Public Interest?

Nancy Dean Beaulieu

NBER Working Paper No. 10127

December 2003

JEL No. I1, L3

\begin{abstract}
$\underline{\text { ABSTRACT }}$
Recently, not-for-profit health plans have been converting to for-profit status and these conversions have frequently occurred as steps to facilitate merger or acquisition with a for-profit company. Some industry observers attribute these managed care market place trends to an industry shake out resulting from increased competition in the sector. At the same time, the perceived competitive pressures have led to questions about the long run viability of non-profit health plans. Furthermore, some industry and government leaders believe that some non-profits are already conducting themselves like for-profit health plans and question the state premium tax exemption ordinarily accorded to such plans. This paper develops a framework for evaluating health plan conversions and examines related health policy issues through the lens of a case study of the proposed conversion of the CareFirst Blue Cross Blue Shield Company. Analyses demonstrate that CareFirst wields substantial market power in some segments of its local market, that it is unlikely to realize cost savings through expanded economies of scale, and that quality of care appears to be lower in the plans typically acquiring converting health plans.

Nancy Dean Beaulieu

Mellon Hall A4-5

Harvard Business School

Soldiers Field Road

Boston, MA 02163

and NBER

nbeaulieu@pop.hbs.edu
\end{abstract}




\section{Introduction}

In 1994, the Blue Cross and Blue Shield (BCBS) Association changed its by-laws to allow members to convert to public stock companies. This touched off a streak of conversions and health plan combinations. To date, 14 BCBS plans have converted to forprofit plans and a few more have conversions pending. There has also been consolidation among BCBS plans; in 1996 there were 63 BCBS plans in operation, in 2003 there are 41. In many instances BCBS plans have converted with the explicit intention of being acquired or merging with another firm; hence conversions and consolidation are intertwined. This has certainly been the case for two BCBS plans that have led the consolidation. Anthem, Inc. is a publicly-traded BCBS plan that was built up through the acquisition of exclusive BCBS licenses in 9 states. WellPoint, Inc. began with the conversion of the California Blue Cross Association and has grown to the largest BCBS company with operations in California, Georgia, and Missouri. ${ }^{1}$ There has been regional consolidation among non-profit BCBS plans as well (e.g. the Regence Group with operations in Washington, Oregon, Utah and Idaho).

These changes among BCBS Association members have occurred against a backdrop of the growing presence of national managed care companies and for-profit health plans in the HMO industry. As shown in Figures 1 and 2, HMO enrollment increased 173\% over the time period 1987 to 2001 . Nearly three quarters of the increase is attributable to enrollment growth in for-profit health plans; $50 \%$ of the enrollment growth occurred in for-profit national managed care plans. Some industry analysts have argued that the rise of national managed care companies has precipitated conversion and consolidation among BCBS plans.

\footnotetext{
${ }^{1}$ Standard \& Poor's, Ratings Direct, Research Report: Blues Convert to For-Profits to Compete, November 12 , 2002.
} 
Each of the conversion cases is unique. Local health plan markets are unique, and so the health plans that operate in them evolve with a unique history. Thus, the evaluations of specific conversion petitions (and possible acquisitions and mergers) must take into account factors unique to each market. However, there are policy issues common to all conversions and in this chapter I develop a framework for analyzing these issues and clarifying the tradeoffs faced by policymakers.

Following a general discussion of the policy issues and the development of an analytic framework, I present a case study analysis of a particular conversion petition. In January of 2002, the CareFirst Corporation filed applications to convert to public stock ownership with insurance commissioners in the states of Delaware and Maryland, and in the District of Columbia. CareFirst's conversion application was explicitly linked to subsequent acquisition by Wellpoint Inc. I present analyses that were conducted for the public advocacy organization, D.C. Appleseeds, to support its participation in the formal proceedings in Washington D.C. At the end of this paper, I will discuss the information gaps that plague research and policy analysis on this topic, opportunities for health economists to contribute to policy in this arena, and the limitations and generalizability of my case study research.

\section{Policy Issues in Health Plan Conversions}

Blue Cross and Blue Shield plans are not the only health plans to convert to public stock ownership. However, the BCBS conversion petitions have sparked the most public debate in part because of the special circumstances in which they were created and because their conversion typically requires a formal determination by a regulatory official; some conversions even require legislation. This chapter deals specifically with BCBS conversions; 
however, several of the health policy issues are germane to other health plan conversions and more generally to the role of not-for-profit organizations in health care.

\section{Origins of the Blue Cross and Blue Shield Plans}

Many of the health policy issues that arise in connection with the conversion to forprofit status of BCBS plans relate in some way to the original creation of the Blue Cross companies. As detailed in Blackstone and Fuhr (1998), most of the Blue Cross plans were initiated by the hospital industry in the 1920s and 1930s to provide hospital insurance at a time when hospitals had declining occupancy rates and escalating operating costs. Typically, these plans were established through state legislation as public benefit organizations and intended to serve as insurers of last resort. In enacting legislation to establish the Pennsylvania BC plan in 1937, Representative Herbert Cohen remarked:

"The Legislature of Pennsylvania in approving this law was attempting to meet a severe need of providing citizens of Pennsylvania with hospital care at a cost within their means and also of providing hospitals with a source of financial support which would place them in a more stable financial position and therefore less dependent upon state and local tax funds. The Legislature therefore was attempting to fill a gap created by commercial insurance companies' underwriting policies which left the mass of Pennsylvania citizens unprotected from hospitalization expenses and hospital bills in many instances unpaid." ${ }^{2}$

The plans were exempted from state income taxes on premiums and in return were subject to various regulations and charged with a public service commitment. Blue Shield plans were created to provide insurance for physician services. The two insurance associations merged into the BCBS Association in 1982. ${ }^{3}$

Non-profit BCBS Plans and the Public Interest

\footnotetext{
${ }^{2}$ Quoted in Blackstone, Erwin A. and Joseph P. Fuhr, 1998. "Blue Cross: Health Insurance," in Market Dominance, edited by David I. Rosenbaum, Westport, CT: Praeger Publishers, pp. 179-180.

${ }^{3}$ Blackstone and Fuhr, 1998. "Blue Cross: Health Insurance"
} 
Because these plans were chartered as tax-exempt organizations for public benefit, state insurance commissioners are obligated to assess whether conversion to a public stock company is in the public's interest. In addition, in the case in which conversion precedes the sale of a BCBS plan, ${ }^{4}$ the insurance commissioner must ascertain that the public receives fair value for the plan from the acquirer. ${ }^{5}$ In some instances, the proceeds of the sale are placed in a foundation; these funds are often used to meet the original objectives of the BCBS plans - to provide access to health care services for those in need. ${ }^{6}$

In reaching a judgment on whether conversion advances the public interest, state insurance commissioners are likely to take into account the potential effects of conversion on multiple stakeholders. For example, the insurance commission will want to know how conversion will affect insurance coverage for vulnerable populations and reimbursement to providers. This analysis of the effects of conversion will require an understanding of how, if at all, the behavior or conduct of the health plan might change as a result of the conversion and potential sale or merger. There are at least six dimensions of health plan conduct that the insurance commissioner may consider:

Products Offered and Markets Served. Most health plans offer a number of different health insurance products and some of these products are tailored for particular subpopulations. Products may differ on several dimensions (e.g. the provider network, reimbursement for care provided by providers not in the network, coinsurance and

\footnotetext{
${ }^{4}$ Most BCBS plans convert to a public stock company as a step toward merging with or being acquired by another BCBS plan; the existence of publicly traded stock facilitates the ownership transfer and combination.

${ }^{5}$ One of the Association's by-laws requires that the use of the BCBS trademark can only be acquired by another BCBS plan.

${ }^{6}$ The financial proceeds from the conversion and sale or initial public offering of a BCBS plan do not always endow a public trust or charitable foundation. Jamie Robinson describes the factors that led the state government to benefit financially from the conversion of Empire, Blue Cross and Blue Shield of New York ("The Curious Conversion of Empire Blue Cross," Health Affairs, vol. 22(4):100-118, July/August 2003).
} 
copayment rates, services covered (i.e. benefit design), and maximum payments under the policy). In some states, not-for-profit health plans are required to offer plans in which any person may enroll without regard to the individual's age, employment status, health status, or any other factor which might otherwise cause the individual to be denied health insurance. These plans are sometimes referred to as open enrollment plans. In deciding on the set of health insurance products to offer, health plans make implicit choices about whether to serve certain subpopulations. For example, not all health plans choose to offer a Medicaid or Medicare product; other noteworthy subpopulations include the small business segment, the individual policy segment, and the Federal Employees Health Benefits Program (FEHBP).

Quality of Care. There are a number of ways in which health plans can influence the quality of health care services delivered to enrollees. Many of these levers require financial outlays by the health plan for patient and physician education, information systems, and program design and administration. For example, health plans may design and implement chronic disease management programs.

Quality of Service. Health plans have frequent interactions with enrollees about coverage issues, the status of particular claims, and the plan's provider network. The manner in which these inquiries are resolved may not directly affect quality of care but may indirectly affect access to care.

Pricing and Underwriting Practices. In some states, health insurance premiums for particular managed care products are community rated; this means that the insurance regulator has eliminated the health plan's pricing decision and requires all plans serving a specific population to charge the same premium. In other states, premiums (and benefit design) for some products are subject to review by the insurance regulator. In yet other 
states, there is no regulatory oversight of health plan pricing policies. Depending on the regulatory regime of the state in which the health plan is operating, there may be additional scope for the health plan to adjust premiums based on the risk factors of the group (or individual) to be insured. These are the firms underwriting policies.

Provider Networks and Reimbursement. In most states and for most products, health plans have a free hand in deciding which providers to include in their networks and in negotiating the level and the form of reimbursement for services delivered to enrollees. ${ }^{7}$ Anecdotally, it is frequently noted that some health plans reimburse at levels substantially above or below other health plans in the same market. Health plans may institute other policies that make it more or less difficult for the physician to be reimbursed for health care services. For example, some providers criticize utilization review and pre-certification as burdensome interventions that increase physicians' costs of delivering care and decrease patients' access to care.

Public and Community Health Efforts. Most health plans earmark some resources for outreach efforts intended to improve the health of community members irrespective of enrollment in the health plan. These efforts include such measures as free screening for certain diseases and public health education.

Changes in the conduct of the health plan in any of the above mentioned areas could influence access to health care, insurance coverage, the quality of health care services provided, health status in the population, the financial health of providers, and the costs of health insurance to individuals and employers.

\footnotetext{
${ }^{7}$ A recent Supreme Court ruling upheld so-called "any willing provider" laws enacted at the state level which require health maintenance organizations to accept any qualified doctors who wants to join the HMO's provider network ("Justices: States can force HMOs to open networks," by Bill Mears, CNN.com, April 2, 2003)
} 


\section{Necessary Conditions for Changes in Health Plan Conduct}

Whether the conversion or conversion/sale of a health plan is likely to alter the health plan's conduct on any of the above dimensions hinges on two conditions. First, depending on the regulatory environment and the nature of the market in which the health plan operates, there may or may not be scope for the plan to change its conduct on some of these dimensions. For example, it may be that all health plans operating in a particular state, regardless of their tax status, must reimburse hospitals according to the same mandated fee schedule. An alternative potential constraint on health plan conduct may be present in the level of market competition. Consultants to one health plan applying for conversion have argued that the market in which the health plan was operating was so competitive as to effectively limit the prices the health plan could charge and still attract enrollees. ${ }^{8}$

The second condition necessary for a conversion or a conversion/sale to result in a change of conduct is that such change must be expected to increase the (short or long term) profitability of the health plan. Conceptually, a converting health plan could increase profitability in three ways. First, it could terminate the practice of cross-subsidizing premiums on unprofitable insurance products or subsidizing care delivery by certain providers. Eliminating a subsidy or cross-subsidy could increase profits but only at the expense of one of the stakeholders (i.e. some population of consumers or providers); thus this type of change in conduct would amount to a value transfer from consumers and/or providers to shareholders.

The second mechanism through which a converting health plan may increase profits is through investment in new products and technologies. There are two examples in this category that come to mind. Some market observers and participants allege that not-for-profit health

\footnotetext{
8 "Community Impact Analysis of the Proposed Conversion of CareFirst, Inc.," a report produced by Accenture for CareFirst BlueCross BlueShield, January 2002.
} 
plans have limited access to capital and therefore may be unable to make the necessary investments that would lead to new products or lower costs. It may also be that non-profit health plans are subject to some organizational inertia and that, while they possess the necessary resources and capabilities, they do not feel compelled to innovate. This organizational inertia could be attributable to insulation from competitive pressure afforded by the state tax exemption on premiums. A change in conduct of this nature could lead to value creation since consumers would benefit from new products and reduced costs.

The third mechanism through which a converting health plan may increase profits is through improved efficiency resulting from enhanced accountability and governance structures. In non-profit organizations, the residual claimants to the surplus created by an organization are unclear. Those who make decisions for the organization do not have a clear objective function; consequently it is difficult to identify suitable performance measures, structure appropriate incentives, and to hold decision-makers accountable. Reducing inefficiency through improved accountability and governance structures is a value creating activity because it results in services being delivered at the lowest cost to society overall.

Recall that the insurance commissioner must make a determination of whether a conversion is likely to advance the public interest. If the expected changes in health plan behavior do not have the potential to create additional value and are simply a transfer from consumers and providers to prospective shareholders, it would seem difficult to argue that the conversion is in the public interest. If on the other hand, the expected changes in health plan behavior are likely to result in new and better products, conversion may indeed advance public welfare. In all likelihood, a health plan conversion will have the potential for both value creation 
and value transfer. In these cases, the insurance commissioner must in essence make a judgment that involves tradeoffs between different stakeholders.

\section{Other Considerations Beyond Changes in Health Plan Conduct}

Changes in health plan conduct are only the most straightforward of considerations in evaluating whether conversion is in the public interest. The simple alternatives of approving or denying the conversion petition are more complicated than they might seem at first glance. The consequences of approving the conversion are not simply the anticipated costs and benefits of changes in health plan conduct; one must also consider the opportunities afforded by an endowed foundation charged with the mission of serving the public interest. Similarly the consequences of denying the conversion are not simply the preservation of the status quo. One must consider the factors that prompted the conversion petition in the first place and what they signal about the evolution of the local health care market and the viability of the health plan petitioning to convert.

To assess whether a foundation could more efficiently execute the public service mission of a non-profit health plan, it will be instructive to first evaluate the extent to which the petitioning health plan is currently executing this mission and to approximate the resources it requires (both financial and organizational) to do so. Only then can one make a determination about whether a foundation could accomplish the same task at a lower cost or implement an expanded mission with the funds available from the conversion.

Oversight of a not-for-profit health plan's execution of its mission is not typically considered to be in the purview of state insurance regulators and is largely delegated to board members. There is some question as to whether these not-for-profit health plans are completely fulfilling their missions as public benefit organizations. In written testimony submitted to the 
Maryland Insurance administration in March 2002, William Jews, the CEO of the CareFirst Blue

Cross Blue Shield Company explains when and why the Blue Cross Blue Shield of Maryland

(BCBSMD) plan stopped filling the role of "insurer of last resort":

"As with other Blues Plans being formed at about the same time, the [Blue Cross Blue Shield of Maryland plan] was conceived with the goal of providing affordable health care insurance using "community rating" principles. This worked effectively at a time when few, if any, commercial carriers were offering health coverage. In the 1960s, commercial insurance carriers began entering the health insurance market in earnest and introduced the concept of "experience rating". As commercial carriers focused on providing coverage at lower premiums to the healthiest individuals and groups, Blues Plans like BCBSMD continued to extend coverage to all comers, including high risk customers through its community rating mechanism. As a result, many Blues Plans became known as "insurers of last resort" in their service areas ..."

That role of insurer of last resort changed in the 1960s when the federal government - in essence - assumed the mantle of insurer of last resort by establishing the Medicare and Medicaid programs to guarantee health covered to the aged and disabled and to provide coverage to the poor. From that point forward, Blues Plans began to compete with commercial insurance carriers and the longstanding expectation that "Blues" would act as the insurer of last resort was greatly minimized. In addition, the continued use by our competitors of experience rating, which gave them an unfair advantage, forced most Blue Plans to abandon community rating in order to survive."

Jews contends that the creation of public insurance programs by the federal government relieved the Blues plans of fulfilling their role as insurers of last resort. If the public service mission of BCBS plans is limited to the narrow interpretation of providing affordable health insurance using community rating, and if this mission has been abandoned by BCBS plans seeking to convert, then the insurance commissioner's decision of whether to approve a conversion petition is somewhat simplified. Under the current organization and governance structure, the not-forprofit plan is receiving a tax exemption while operating in a manner closely resembling that of a for-profit health plan; the foregone tax receipts and the alternative uses of the plan's assets are the opportunity costs of disallowing the conversion and requiring the health plan to continue in 
the status quo. In these circumstances, this line of reasoning should eliminate the alternative of denying the conversion petition and maintaining the status quo.

However, the insurance commissioner may decide that the public interest would be better served by going beyond denial of the petition and instituting reform of the health plan governance structures and accountability systems to ensure that it pursues its original mission. Whether or not this is the best course of action hinges on two additional analyses: 1) an assessment of whether the mission will be executed more efficiently by a suitably reformed nonprofit health plan or a newly created foundation, and 2) whether either institution is viable in the long run.

In the above statements, Jews asserts that the BCBSMD plan was compelled to abandon its original mission in order to survive competition from commercial insurance carriers. These views are echoed in a recent account of the conversion of the Blue Cross and Blue Shield plan of New York. ${ }^{9}$ Jamie Robinson recounts how state regulators destroyed the delicate balancing act of cross-subsidization achieved by Empire BCBS when the regulators allowed commercial insurers to enter the market and attract the healthy low-cost enrollees with lower premiums. These actions precipitated an adverse selection spiral that left Empire with the sickest enrollees and the highest costs. In general, the long-term financial viability of an efficient non-profit is unknown. There is also limited research on the regulatory structures that might support a nonprofit health plan and the social efficiency of such regimes.

The foregoing analysis suggests a framework to guide research and decision-making on health plan conversions (see Figure 3). Prior to evaluating the potential changes in health plan conduct and the effects of these changes on public welfare, the insurance commissioner might first want to consider:

\footnotetext{
${ }^{9}$ Robinson, James, "The Curious Conversion of Empire Blue Cross," Health Affairs.
} 
1. Whether the public interest mission of the not-for-profit can be achieved more efficiently through a foundation or a health insurance plan; and

2. Whether any organization can faithfully execute this mission and remain financially viable.

After making these assessments, the insurance commissioner must then weigh the costs and benefits to different constituencies of likely changes in health plan conduct.

\section{Case Study}

In the previous section of this paper, I have described, in a generic sense, some of the health policy issues that arise when a not-for-profit health plan petitions a state insurance regulator to convert to a public stock company and potentially to be acquired by another company. In this section, I present some case study research conducted when the CareFirst Blue Cross and Blue Shield Company (with licenses in Delaware, Maryland, and Washington D.C) petitioned to convert to a public stock company and to be acquired by Wellpoint Health Networks, Inc. I will provide a brief description of the CareFirst organization and the events leading up to the conversion petition. I will then summarize the main arguments both for and against the conversion as they have been presented in oral and written testimony, in publicly available reports, and in the public press. Next, I will present the results of analyses of market structure, economies of scale, and quality of care. Finally, I will report on the outcome of the petition and the research challenges remaining.

\section{Background on Carefirst}

CareFirst, Inc. is a holding company with BCBS licenses for Delaware, the District of Columbia, and Maryland. The company was formed in 1998 with the merger of BCBS of 
Maryland and BCBS of the National Capital Area (District of Columbia). In 2000, BCBS of Delaware became part of CareFirst.

CareFirst is overseen by a central board of directors; William Jews is the CEO of CareFirst and CEO of each of the three subsidiaries that make up Carefirst: Group Health and Medical Services Inc. - GHMSI (the D.C. Blues), CareFirst of Maryland (the Maryland Blues) and BCBSD (the Delaware Blues). The CareFirst corporation offers a wide variety of insurance products in these three jurisdictions.

In November of 2001, CareFirst entered into a merger agreement with Wellpoint Health Networks, Inc. of California. To consummate this merger agreement, CareFirst needed to convert to a for-profit public stock company. The insurance commissioners in all three jurisdictions in which CareFirst operates needed to approve the conversion petition; however, Maryland was the first jurisdiction to initiate formal proceedings to evaluate the merits of conversion. As part of the proceedings in Maryland and in the District of Columbia, public hearings and discovery were held to generate information to inform the public interest determination. Valuation studies of CareFirst were also initiated.

\section{Summary of arguments for and against conversion}

The CareFirst management team and its consultants advanced three primary reasons in support the conversion petition. First, they cited an inability to access sufficient capital to fund investments that would enhance efficiency, improve customer service, and facilitate the development of new and better products. However, in the consultant's report and in CareFirst's strategic plan it appeared that the need for capital was largely driven by plans for acquiring other health plans. The need to achieve economies of scale was cited as the primary reason for this acquisition strategy. Second, without these improvements (and larger scale), they contended that 
CareFirst's long run viability is uncertain. Approving the conversion would therefore "help to secure the long-term future of the "Blue" brand in local markets". ${ }^{10}$ Third, approving the conversion and merger with Wellpoint would benefit the public because it would result in additional tax receipts (estimated to be $\$ 20$ million annually) and the creation of a foundation with an endowment of $\$ 1.3$ billion that would be apportioned to the three jurisdictions.

Those opposing the conversion cited a variety of concerns, many of which related to the future conduct of a for-profit BCBS plan. Concerns about access to care stemmed from the expectation that after conversion, CareFirst would discontinue offering insurance products that served vulnerable populations and that were relatively unprofitable. Some people feared that CareFirst would raise premiums, tighten underwriting practices (abandon guaranteed issue), and narrow the coverage of the insurance policies it continued to offer. Another policy concern related to the potential for skimping on quality. Some providers were not supportive of the conversion petition because they feared reductions in payment rates, increased administrative burden, and a more adversarial relationship. Both providers and consumers feared the loss of a local institution led by members of the community with long run interests of the community in mind. Two objections to the conversion were unrelated to anticipated changes in health plan conduct. Some people felt that Wellpoint's offer of $\$ 1.3$ billion to acquire CareFirst was less than the fair value of CareFirst as an ongoing concern. ${ }^{11}$ Finally, many consumers were outraged at bonuses CareFirst executives were scheduled to receive if the deal went through.

\footnotetext{
${ }^{10}$ Testimony of William L. Jews to the Maryland Insurance Administration, March 11, 2002.

${ }^{11}$ Independent valuations of CareFirst by ... found Wellpoint's offer to fall below their assessments of fair market valuation.
} 


\section{Economic Analyses}

\section{Market Structure}

CareFirst executives and consultants have suggested in their filings that the markets in which the CareFirst plans operate are so competitive as to constrain their ability to raise premiums or lower quality without losing enrollees to other local health plans. They imply that CareFirst, if it were allowed to convert to for-profit status, would not take such actions (raising premiums or lowering quality) because the loss of enrollment would decrease profits. Traditionally, economists have used market share summary measures as proxies for market competitiveness. The belief is that greater concentration of market share among a smaller number of firms is likely to result in higher prices.

Computing market shares in practice requires definition of the market and detailed data for each firm. Market definitions can have large effects on both measures of concentration and market shares for individual firms. In this section, I examine the extent of market concentration in the District of Columbia (DC) using data on HMO and managed care enrollment. ${ }^{12}$ I am able to obtain relatively complete enrollment data for health plans licensed to do business in DC; these detailed data facilitate analyses of market share by consumer segment and product type. However, CareFirst sells policies in Maryland, Virginia, and Delaware. A complete analysis of the market power possessed by CareFirst would require comparable analyses in these other geographical markets.

\footnotetext{
${ }^{12}$ These enrollment data are drawn the mandatory reports filed with the Insurance Commissioner's Office by health plans licensed to do business in the District of Columbia and from the national databases assembled by InterStudy. The InterStudy data are limited for the purpose of examining total health plan enrollment (HMO and non-HMO) in the following manner. While InterStudy is recognized as the leading source of data on health plans offering HMO products, the universe of plans in these data excludes health plans that do not offer an HMO product, but includes data on non-HMO products for health plans that also offer an HMO. Hence, the sample of health plans in InterStudy is incomplete in its inclusion of purely non-HMO plans.
} 


\section{Health Plan Enrollment}

Table 1 reports the health plan enrollment and market share for each health plan licensed to sell health insurance policies in the District for the years 2000 and $2001 .^{13}$ In 2001 , there were a total of 14 health plans most of which fall into one of three categories. Four national for-profit companies (Aetna U.S. Healthcare, AMERIGROUP, Cigna, and United Healthcare) did a small amount of business in DC (combined market share of roughly 10.1\%). Three other health plans could be characterized as relatively small regional plans (George Washington University Health Plan, Optimum Choice, and MD-Individual Practice Association) because they operate in a small number of adjacent states. In 2001, these regional plans account for $15.6 \%$ of the market. Four health plans offered products only in the District (Health Right Inc, DC Chartered Health Plan, Advantage Health Plan, and Capital Community Health Plan); together these plans accounted for $3.5 \%$ of the market.

Omitted from this categorization are two CareFirst plans and the Kaiser plan. CareFirst operates two health plans in the District: CareFirst BlueChoice (hereafter BlueChoice) and Group Hospitalization and Medical Services, Inc. (GHMSI). Together these plans represent $50.9 \%$ of the market, however GHMSI with $48.5 \%$ share dominates in this market. Kaiser Foundation Health Plan has the second largest share of the DC market (19.8\%) and does not fit

\footnotetext{
${ }^{13}$ These enrollment and market share data were obtained from the health plan filings with the DC Insurance Commissioners Office except for the enrollment data for the Federal Employees Health Benefits Program (FEHBP). The form filed with the Insurance Commissioners office does not list FEHBP enrollment, but does list the total premiums collected by the plan for this product. The InterStudy database contains data on FEHBP enrollment for nearly all of the health plans operating in the District. The CareFirst plan operating under the name of Group Medical and Hospitalization Services, Inc. (GHMSI) does not offer an HMO product and is therefore not included in the InterStudy database. FEHBP enrollment for GHMSI was imputed in the following manner. Using the premium data from the DC Insurance Commission filings and enrollment data from InterStudy, I computed the average FEHBP premium for all health plans offering an FEHBP plan in the District except for GHMSI. I then imputed FEHBP enrollment for GHMSI by dividing its total FEHBP premiums by the average FEHBP premium in the District.
} 
neatly into any of the above three categories. It is affiliated with the only national not-for-profit health plan in the U.S.

Total health plan enrollment in DC grew 2.9\% from 2000 to 2001. All national for-profit plans lost market share over this time period with the exception of AMERIGROUP (which gained 200 enrollees). Prudential Health Care operated a plan in 2000, but terminated this local plan in 2001 following its acquisition by Aetna Health Plans. Two regional plans experienced substantial increases in enrollment (MD-IPA $+41,000$; Optimum Choice $+18,600)$; the third regional health plan, George Washington University Health Plan lost roughly 18,000 enrollees. GHMSI experienced the largest absolute enrollment gains during this period $(>45,000$ enrollees).

\section{Enrollment by Consumer Segment}

As shown in Table 2, health plans operating in the District sell policies to a number of different consumer segments; however, enrollment in two of these segments (the commercial group and FEHBP segments) constitutes $91.5 \%$ of all health insurance policies sold in DC. The largest market segment is the commercial group market which accounts for $47 \%$ of all health insurance policies; GHMSI and BlueChoice together hold a 51\% share of this segment. Commercial group products are typically sold to employers (large and small) who in turn offer these health plans as a benefit to their employees at some fraction of the per enrollee cost to the employer.

The second largest segment is the Federal Employees Health Benefits Program (FEHBP); the FEHBP segment is very similar to the commercial group segment in that the Federal government essentially acts as a large employer. One difference between these two segments is that any health plan meeting a minimum set of criteria may participate in the FEHBP program 
(i.e. offer a health plan to federal employees); private-sector employers typically selectively contract with a very small number of health plans. The FEHBP market segment is nearly as large as the commercial group segment (44\% of policies). Six health plans in the District offer a policy designed specifically for federal employees, but GHMSI alone holds $51.7 \%$ of the market.

\section{Health Plan Enrollment by Product Type}

Managed care companies typically offer a variety of health insurance products in the commercial group segment of the market. These products vary in terms of the health care providers that members may receive care from and who bears the risk that total premiums may not equal total expenses during the time the policy is in effect. At one end of the spectrum is the HMO product; for HMO policies, the managed care company bears all the risk ${ }^{14}$ and members are restricted to a pre-specified provider network. At the other end of the spectrum is the indemnity product; for indemnity policies (which are very rare today), the policyholder and the managed care company jointly share risk up to some maximum benefit. Policyholders may receive care from any licensed provider.

In between these two extremes are Preferred Provider Organization (PPO) products and Point of Service (POS) products. In both PPO and POS plans, the sponsoring managed care company identifies a preferred list of providers. In the case of a POS, this preferred list of providers is usually the provider network for an HMO product; in the case of a PPO, the preferred providers have entered into contracts with the managed care organization in which they have discounted the fees they charge. When a member of a PPO or a POS seeks care from a provider not included on the preferred provider list, the member will be responsible for a coinsurance payment - a fixed percentage of the total amount the non-preferred provider charges

\footnotetext{
${ }^{14}$ Managed care companies may transfer some of this risk to health care providers through contracts that involve prospective payment (i.e. capitation).
} 
the health plan for his or her services. When a member of a POS plan receives care from a preferred provider, there will typically be no coinsurance payment. When a member of a PPO receives care from a preferred provider, there will typically be a smaller coinsurance payment compared to when services are obtained from a non-preferred provider. Because of differences in their provider networks and their benefit design, PPO products are imperfect substitutes for HMO products.

Table 3 presents statistics on total health plan enrollment by product type in 2001 for health plans operating in the District. ${ }^{15}$ Approximately $71 \%$ of all health insurance products marketed by these health plans in the DC-MD-VA region are HMO products. The next largest category is the PPO product; this product represents $21 \%$ of all health insurance products sold in this region by health plans that participate in the DC market. Note that all health plans offer an HMO product except for GHMSI, and that only GHMSI offers a PPO product or an indemnity product; GHMSI does not compete with any other managed care firm in these two product markets and has the largest market share $(\sim 45 \%)$ in the POS product market. CareFirst BlueChoice membership represents a further $24 \%$ market share in the POS product market.

\section{Market Concentration}

Economists frequently employ the Herfindahl measure to quantify the extent to which market share is concentrated in a small number of firms. The Herfindahl concentration measure is computed as the sum of squared market shares for all firms in the market. If there is only one firm in the market (i.e. monopoly), the Herfindahl equals one. If there are two equally sized firms in the market, the Herfindahl equals 0.5. Economists are interested in market

\footnotetext{
${ }^{15}$ The data on health plan enrollment by product type was taken from health plan filings with the DC Insurance Commission. These data are aggregated at the health plan level and geographical breakdowns were not available (e.g. the number of GHMSI PPO enrollees in the District of Columbia). Furthermore, FEHBP enrollment was not included in these data. With the exception of GHMSI, it appears that all of the FEHBP health plans offered in the District are HMO plans.
} 
concentration because they believe it is related to a firm's bargaining power with suppliers and the ability of individual firms to affect the price at which the market clears.

The Herfindahl statistic for the entire District of Columbia health insurance market is 0.29 ; this is roughly equivalent to having three to four equally sized firms in the market. In some more narrowly defined market segments, the Herfindahl statistics are substantially higher. For example, the Herfindahl statistic in the individual market (policies sold to individual consumers and not through group purchaser) is 0.54 ; GHMSI's share of this market is $72 \%$. The Herfindahl in the FEHBP segment is 0.34 and GHMSI's market share is $52 \%$. In the District, GHMSI is the only managed care firm in the PPO and Indemnity market segments (Herfindahl=1.0). Table 4 presents the Herfindahl statistic and GHMSI's market share for each market segment in which it participates.

\section{Market Dynamics}

Point in time statistics on enrollment and market share provide an incomplete picture of the competitive nature of a market. One might like to know which products, if any, have gained popularity in recent years. Comparable historical data from health plan filings with the DC Insurance Commission were not available to construct a longtitudinal version of Table 1.4. However, enrollment by product type was available from the InterStudy database for the years 1999 and 2001 for any health plan offering an HMO. ${ }^{16}$

Table 5 reports changes in the sum total of enrollment by product type for health plans that offer an HMO and whose primary service area is the District of Columbia, Maryland, or Virginia. These enrollment changes are also broken down by plan ownership type: National For-

\footnotetext{
${ }^{16}$ Recall that the sample of plans included in the InterStudy database is defined by any plan offering an HMO product (hence GHMSI is not included in the InterStudy database). However, once included in the sample, InterStudy reports enrollment in all types of products (not just HMO products). Because of the sample selection, InterStudy may underestimate enrollment in non-HMO products.
} 
Profit, Virginia Blue Cross Blue Shield, Independent (includes for-profit and not-for-profit) and CareFirst. A list of health plans in each ownership category is included as Exhibit 1.

Market-wide, the largest decreases in total enrollment occurred in the commercial group HMO product line and in the open-panel HMO product line. The largest increases occurred in PPO enrollment and enrollment in other non-HMO products. Data in this table suggest that the national for profit firms decreased enrollment in commercial group HMO products and made up for about $83 \%$ of this HMO enrollment decrease with enrollment increases in PPO and other non-HMO products. Unlike other health plans in the DC-MD-VA market, CareFirst plans increased their commercial group HMO enrollment but decreased enrollment in all other HMO products. However, these decreases were more than offset by large increases in PPO enrollment and enrollment in self-insured products.

Comparable nationwide enrollment changes between 1999 and 2001 are presented in Table 6. Similarities between trends in the DC-MD-VA markets and nationwide include a substantial increase in PPO enrollment, a substantial decrease in commercial group and POS enrollment, and a decrease in non-group direct enrollment products. In contrast to nationwide enrollment trends, total managed care enrollment, FEHBP enrollment, and public program enrollment decreased in plans offering an HMO in the DC-MD-VA market while they increased nationwide. Overall, however, it seems that enrollment trends in the DC-MD-VA market area are very similar to enrollment trends nationwide.

In summary, the market share analysis indicates that the CareFirst plan, GHMSI, dominates the DC health insurance market. GHMSI has very large market share in the largest consumer segments. Furthermore, the markets in which GHMSI dominates are also very concentrated. This combination suggests that GHMSI possesses market power in DC. The next 
largest plan in the DC market is the Kaiser plan; it is noteworthy that the national for-profit health plans that CareFirst managers perceive as their primary competitors hold relatively small market shares in DC. Since the market structure analyses were limited to the DC market, it is not possible to speculate whether other CareFirst plans possess similarly favorable positions in the Maryland and Delaware markets.

National and local enrollment trends suggest a decline in traditional HMO and POS products and increases in $\mathrm{PPO}$ and other non-HMO products. CareFirst plans are at the forefront of this trend in the PPO market but lag behind the national for-profit firms in the market for other non-HMO products.

\section{Economies of scale}

CareFirst executives and consultants have argued that the firm's acquisition by Wellpoint will lower CareFirst costs because of economies of scale. Strictly speaking, economies of scale are present when average unit costs fall with increased output. Average unit costs may decrease over some range of output for two reasons. First, large capital investments represent fixed costs that lead naturally to declining average costs up to some capacity constraint. Second, marginal costs may fall over some range of output because of learning curves, specialization, or volume discounts from suppliers.

In the health insurance market, economies of scale would be present when the average total cost of insuring an individual are lower with high levels of total health plan enrollment than with low levels of total plan enrollment. There are a number of intuitive reasons why economies of scale might be present in managed care operations. First, insurance is largely an information business and requires substantial capital investment in computers and software to manage that information. As long as the information systems are not at some capacity constraint, the IT costs 
of processing information for an additional enrollee is essentially zero; hence health plans can lower average costs by spreading these fixed costs of capital investment over a larger enrollment base. In a similar vein, health plans with a larger enrollment base may be able to support a larger R\&D group and have more opportunities for lower cost experimentation with new products and processes. There are also fixed costs associated with negotiating contracts with health care providers and purchasers.

Second, greater health plan enrollment may increase the bargaining power that the health plan can exercise in its negotiations over reimbursements with health care providers (e.g. doctors, hospitals, pharmaceutical companies). The extent to which increased enrollment translates into greater bargaining power and lower medical care costs (and hence lower average total costs) will depend on local market characteristics. In markets where providers are themselves consolidated into large bargaining units, or in which there is strong demand for certain types of providers (e.g. a high quality teaching hospital), the health plan's financial return to greater enrollment that derives from increased bargaining power will be lower.

A third potential source of economies of scale in health insurance relates to the amount of financial reserves that a health plan must hold to meet statutory requirements. For statistical reasons, the per-enrollee amount of financial reserves that a health plan is required to hold will be less for health plans with larger enrollment bases.

If we define economies of scale as average costs falling with increased enrollment, then it is possible to test for the presence of economies of scale in health insurance using a dataset on health plan costs, enrollment, and other characteristics. The following paragraphs report the results of such an analysis. 
Most states require health insurance plans to file quarterly and/or annual reports with the state insurance commissioner using a common format created by the National Association of Insurance Commissioners (NAIC). These data are publicly available. The Weiss Ratings Company collects and compiles these data and sells reports based on these data. In the data compiled by Weiss Ratings are reports of total health plan administrative expenditures, total health plan medical expenditures, total health plan enrollment, and a number of characteristics on the health plan and the insurance products it markets.

The sample for analysis was created by selecting all health plans classified as HMOs in the Weiss data reporting positive enrollment in 2001. These selection criteria yielded a sample size of 439 health plans. Health plans that exclusively enrolled Medicare beneficiaries (11 plans) or Medicaid beneficiaries (60 plans) were dropped from the analysis. Health plans reporting fewer than 5000 enrollees (27 plans, 5 of these plans were Medicaid only or Medicare only plans) were also dropped from the sample. The remaining health plans were matched with the InterStudy database to collect additional information about the plans (321 matches out of final Weiss sample of 347). Missing data for variables used as regressors led to a final sample size of 299 plans.

Figures 4 and 5 show substantial variation in the measure of administrative and medical expenses per member. The correlation between administrative and medical expenses is positive but not very large (correlation coefficient $=0.55$ ). There is no reason to expect that scale economies in administrative expenses would be the same as scale economies in medical expenses. In fact, the earlier discussion suggests different sources of scale economies in the two types of expenditures. For this reason, separate analyses were conducted to test for scale economies in medical expenses and administrative expenses. 
Figure 6 is a frequency distribution of health plan enrollment. This distribution is heavily skewed to the left; there are a relatively small number of plans with very large enrollment (i.e. $>500,000)$. On the lower end of the plan size distribution, note that $56 \%$ of health plans in this sample have HMO enrollment under 100,000 members. One indication of the presence of scale economies is the distribution of medical and administrative expenses for health plans in the top enrollment decile. If scale economies were present, one would expect to see an overrepresentation of these high-enrollment plans in the lowest deciles for average per member medical and administrative expenses. Figures 7 suggest that this is not the case; the high enrollment plans are evenly represented in the administrative expense deciles and overlyrepresented in the higher medical expense deciles.

Figure 8 is a scatterplot of administrative expenses per member against health plan enrollment. Though many health plans are clustered in the low enrollment / low administrative expense quadrant of the graph, there does appear to be a negative relationship between average administrative expense and enrollment. In contrast, there appears to be no relationship discernible from the scatterplot of per member medical expenses and enrollment (Figure 9).

A number of health plan characteristics could influence average administrative and medical expenses independent of scale. Accounting practices in non-profit health plans tend to result in a larger number of expenses classified as administrative compared to for-profit health plans. There are also reasons to suspect that the average administrative and medical expenditures may differ by product line because of the variation in costs of delivering care to enrollees in different market segments. The InterStudy data records enrollment in several different product lines including commercial HMO, FEHBP, Medicare Risk HMO, Medicare supplemental, Medicaid Risk HMO, POS, PPO, and FFS. Not all plans offer all of these 
products. In addition to the types of products offered by health plans, the total number of products may be positively related to average administrative costs. Since different product lines will require product-specific investments in marketing, regulatory compliance, and provider networks, health plans concentrating their enrollment in fewer products would be more likely to experience lower administrative expenses and possibly greater economies of scale.

Administrative and medical expenses per member may also be related to the health plan's provider network organization. There are four basic types of provider networks: (1) the staff model in which physicians are employed by the health plan and located in a small number of clinics, (2) the group model in which health plans contract with physicians practicing in medical groups that may also contract with other health plans, (3) the Independent Physician Association (IPA) model in which physicians in solo and group practice contract with an intermediary (the IPA) which in turn contracts with the health plan, and (4) the network model in which health plans contract directly (not through an IPA) with a mix of solo-practice and group-practice physicians. Today, the provider networks of most health plans are a mix of these four model types. The organization of the health plan's provider network is related, but not identical to, the breadth of the network (measured as the number of physicians per member). Health plans with predominantly IPA-based networks tend also to have larger networks.

Health plans contracting with a large number of providers for a given membership size will likely have larger administrative costs per member due to the additional transaction costs involved in negotiating and executing a larger number of contracts. It is also plausible that health plans with larger provider networks (controlling for membership size) will have higher medical expenses per member for three reasons: (1) adverse selection, (2) the health plan will find it more difficult to control utilization with a larger network and a smaller number of 
enrollees per provider, and (3) the health plan will be less able to negotiate lower provider reimbursement rates when providers see few of the plan's enrollees.

In addition to the network characteristics discussed in previous paragraphs, the method of provider payment may influence average administrative and medical costs. Consider two primary reimbursement methods: fee for service and capitation. Fee for service reimbursement requires the processing and payment on a claim to an individual physician every time a service is delivered. In contrast, capitation reimbursement sometimes involves no filing and processing of individual claims and only a monthly per member payment to the physician or the practice. In some cases, health plans employing capitation will require providers to submit dummy claims that the health plan will then process, but the health plan will still make payments less frequently. It is also likely that capitation would reduce per member medical costs.

In the last decade there has been substantial consolidation of enrollment into a relatively small number of national and regional health plans. This trend might be explained by either a scale economies or a market power argument and has important implications for the empirical estimation of scale economies. Consider a local health plan that is owned by a managed care company with a national presence (i.e. one of the local Aetna Health plans). A statistical analysis of the relationship between local health plan enrollment and local health plan expenditures (both medical and administrative) that failed to account for affiliation with a national managed care company would underestimate the true extent of scale economies. ${ }^{17}$ Affiliation with a national or regional managed care company should convey economies of scale to a local plan to the extent that the cost of centralized services (i.e. claims processing) can be spread over a national or regional enrollment base.

\footnotetext{
${ }^{17}$ This is true only to the extent that local health plan enrollment is independent from (not correlated with) total regional or national enrollment.
} 
Finally, a health plan's medical and administrative expenses may depend on characteristics of the local health care markets in which it operates. There is substantial geographical variation in the organization of the provider sector, regulatory environment, and the extent of mandated benefits that could lead to differences in health plan cost structures.

Any one of these health plan or market characteristics could have an impact on average health plan administrative and medical expenditures. To empirically assess whether there are economies of scale in health plan enrollment it is necessary to statistically control for these other factors. Consequently a regression analysis was undertaken to assess the relationship between health plan enrollment and average per-member administrative and medical expenses.

Table 8 presents the results of two regression analyses. In column two, the dependent variable is administrative costs per member; in column three, the dependent variable is average medical costs per member. A fixed effect for the health plan's primary state of operation (the state in which the health plan had the greatest enrollment) was included in each regression to control for regional variation in expenses. The estimated coefficients presented in columns two and three indicate small but significant economies of scale are present in both administrative expenses and medical expenses. Because both the dependent variable and the enrollment variables are measured in natural logs, the coefficients on the enrollment variables in the regression may be interpreted as elasticities (e.g. the percentage change in administrative expenses associated with a one percentage change in enrollment). The estimated coefficient on "within-plan" enrollment is -0.05 for administrative expenses and -0.06 for medical expenses indicating that a one percentage increase in the health plan's enrollment is associated with a .05 to .06 percentage point decrease in average administrative and medical costs, respectively. These estimated relationships are graphically depicted in Figures 10 and 11. 
Recall that for plans affiliated with National or Regional Managed Care Companies, the total national or regional enrollment was entered separately into the regression. The coefficients on these variables indicate the extent to which the additional scale (enrollment) present in a national or regional managed care company is associated with higher or lower administrative expenses per member in the local plan. The point estimates on these enrollment variables in both regressions are essentially zero and insignificant.

Given that the topic of this paper, it is perhaps worthwhile to note that this regression analysis suggest that non-profit health plans have significantly higher per member administrative costs but not significantly different average medical costs. However, as noted earlier, this finding may be an artifact of non-profit accounting customs.

In summary, the regression analysis finds evidence of modest economies of scale in both administrative and medical costs. The estimated scale economies are nearly exhausted at an enrollment of roughly 800,000 . Only 12 health plans in our sample have an enrollment greater than this. In addition, it appears that there are no additional scale economies to be gained through membership in a regional or national managed care company.

\section{Quality of care}

Consumers, providers, managers, and researchers all acknowledge that quality in health care is multi-dimensional and difficult to measure. These characteristics of quality lead to difficulties in contracting for a specified level of quality and challenges in holding individuals and organizations accountable for the quality of health care services delivered. Quality of care arises as an issue in health plan conversions because there is the potential opportunity and financial incentive for a for-profit health plan to skimp on the aspects of quality that are difficult consumers to observe and verify. 
Differences in quality between health plans do exist and are sometimes large. For example, the Centers for Disease Control estimates that nearly 16 million Americans have diagnosed or undiagnosed diabetes. If not properly managed, diabetes can have devastating health consequences and can consume lots of expensive health care resources. To manage their disease, diabetics and their physicians must know the level of the patient's Hemoglobin A1c $(\mathrm{HbAlc})$ and this information is obtained through a simple blood test. In the sample of plans reporting data to the National Committee on Quality Assurance in 2000, the percentage of diabetic plan members who had their HbAlc tested ranged from $24 \%$ to $97 \%$. This range suggests substantial variation in performance and ample room for improvement. Research has shown that health plans that undertake diabetes disease management programs can effect substantial improvements in care and short-term outcomes for diabetics.

Published health services research documents correlations between health plan performance on some quality measures and a variety of health plan characteristics. ${ }^{18}$ Though the root causes of these patterns are not well understood, local independent and non-profit health plans frequently outperform for-profit publicly-traded national managed care plans. These findings are important for public officials to consider as they determine whether particular conversions are in the interest of health care consumers. In the following paragraphs, I compare the performance of CareFirst, Wellpoint, and other health plans operating in their respective markets on a variety of measures of health plan quality.

\section{Measures of Health Plan Quality}

In 1997, the National Committee on Quality Assurance (NCQA) began reporting the performance of some health plans on a selected set of quality measures. This set of measures (called HEDIS - the Health plan and Employers Data Information Set) was chosen by a group of

\footnotetext{
${ }^{18}$ Woolhandler \& Himmelstein, Landon et al.,
} 
health care purchasers and medical professionals and has been expanded over the years. Health plans voluntarily submit performance data (most is audited) to the NCQA who then publishes these data in a product called Quality Compass. Consumers and employers have used these data to help them make health care purchasing decisions; academic researchers have used these data to study the causes of variation in health plan quality.

The HEDIS measures convey information about the extent to which the health plan's enrollees are obtaining preventive services and diagnostic tests necessary for managing certain chronic diseases (see Exhibit 3 for a list of HEDIS measures used in the analyses presented in this report). The HEDIS set also includes a few measures of health care outcomes for the health plan's enrolled population that signal, overall, how well the health plan is doing at helping its members stay healthy.

The second set of measures used in this analysis of health plan quality is derived from a survey instrument called the "Consumer Assessment of Health Plans Survey (CAHPS)". The survey is administered by an independent party to a random sample of the health plan's enrollees to collect data on consumers' experiences in seeking and obtaining health care. Health plans often submit their performance on CAHPS to organizations that publish comparative health plan data (such as the federal government, the NCQA, and local health care purchasing groups). The federal government has mandated the collection and reporting of these survey data for Medicare beneficiaries enrolled in Medicare HMOs.

The CAHPS instrument generates hard to find data on the quality of enrollees interactions with providers and health plans (see Exhibit 4 for a list of CAHPS measures used in the analyses presented in this report). Health plans can take many actions to facilitate consumers' access to care, to educate and involve consumers in their own health care, to ease the 
administrative burden of dealing with insurance claims, and to select and support a provider network that routinely delivers high quality patient-friendly care. The CAHPS measures provide health plans an opportunity to distinguish themselves in these areas.

\section{HEDIS comparisons}

CareFirst operates three separate health plans in the Mid-Atlantic region that reported 1999 HEDIS data to NCQA (the data are published in Quality Compass 2000): CapitalCare Inc., Delmarva Health Plan Inc., and FreeState Health Plan Inc. In the analyses that follow, an average score is computed for all three CareFirst plans weighted by HMO enrollment. Wellpoint operates the Blue Cross of California health plan (BC-CA) in California; this plan reported a limited set of 1999 HEDIS data to NCQA. Performance on HEDIS measures may be influenced by some factors beyond the health plan's control such as socio-demographic characteristics of the plan's membership, local organization of providers, and state health initiatives. To control for variation in some of these factors across markets, the HEDIS scores of each plan have been adjusted for the region of the country in which the health plan operates.

Table 8 presents HEDIS data comparing the average performance of the CareFirst plans to Wellpoint's California plan and to the national average on three types of measures: preventive care, chronic care, and mental health care. CareFirst performs least well on the preventive care measures; it's scores exceed the national average on 4 out of 10 measures and BC-CA outperforms CareFirst on 6 out of the 7 measures for which data were submitted by BC-CA. The second group of measures relates to care for enrollees with chronic disease. BC-CA reported only one out of eight measures in this group and its performance on this measure falls significantly below CareFirst's performance. CareFirst outperforms the national average on six out of 8 measures in the chronic care category. Finally in the third group measures relating to 
mental health care, CareFirst outperforms BC-CA on the two measures for which Wellpoint submitted data. CareFirst outperformed the national average on 3 out of 5 measures in this category.

These comparisons between the CareFirst plans and the Wellpoint-CA plan suggest that each of these plans has its strengths and weaknesses and that neither plan dominates the other on HEDIS measures. It is noteworthy that at least one CareFirst plan reported data for every HEDIS measure (23 measures in all), while the Wellpoint-CA plan reported data on just less than half of the measures. The collection and public reporting of plan performance on HEDIS measures signals a plan's commitment to improving health care quality.

Table 9 facilitates a comparison of performance by CareFirst and Wellpoint-CA on HEDIS measures to the Kaiser plans operating in the CareFirst and Wellpoint-CA markets. The Kaiser Foundation is the holding company for the only truly national not-for-profit managed care plan in the United States. Virtually all other not-for-profit managed care companies have only a local or regional presence. The Kaiser Foundation plans in California and the mid-Atlantic region reported a full set of 1999 HEDIS data to NCQA.

Comparing the second and third columns of the table in Table 9, one notes that Kaiser of the Mid-Atlantic outperforms CareFirst on nearly every HEDIS measure (19 out of 23). Second, comparing the second and third columns of the table, one notes that the Kaiser plans of California outperform Wellpoint on nearly every measure for which Wellpoint reported data (10 out of 11). Finally, Kaiser mid-Atlantic outperforms Kaiser California on 16 out of the 23 measures. This comparison of the two Kaiser plans raises the concern that the method used for controlling for systematic geographical variation was not completely successful. However, the 
magnitude of the differences between the Kaiser plans and CareFirst and Wellpoint plans suggests systematic differences even within region.

In summary, there are three major conclusions that emerge from these comparisons on HEDIS measures. First, the CareFirst and the BC-CA plans each have strengths and weaknesses on HEDIS measures and neither plan dominates the other; BC-CA compares favorably on preventive care measures while the CareFirst plans compare favorably on chronic care and mental health care measures. Second, both the BC-CA plan and the CareFirst plans are outperformed by the Kaiser plans in their respective markets on HEDIS measures.

\section{CAHPS comparisons}

This section of the report presents comparisons of the performance of several health plans on the set of CAHPS composite measures published in Quality Compass 2000. Examination of Table 10 shows that the CareFirst plans outperform the BC-CA plan on 8 out of 10 CAHPS measures (the plans are essentially equal on two measures). The largest differences between the health plans' performance relate to access to care - getting care quickly and getting needed care. Table 10 also facilitates a comparison of the BC-CA and CareFirst plans to the national average. BC-CA performs below the national average on 8 out of 10 CAHPs measures; CareFirst performs better than the national average on 7 out of ten measures. It is also noteworthy that the average for national publicly-traded for-profit health plans is below the average for all plans nationally that submitted data on all ten measures.

The Kaiser mid-Atlantic plan outperforms the CareFirst plans on 2 out of the 10 CAHPs measures; in contrast, the Kaiser California plan outperforms the BC-CA plan on 9 out of 10 measures (Table 11). 
In summary, the analysis of CAHPs quality measures suggests that CareFirst members have had more favorable experiences in obtaining health care services compared to the Wellpoint plan in California. Comparisons to local Kaiser plans in each market reinforce the findings of the head to head comparison of $\mathrm{BC}$ of California and the CareFirst plans.

\section{Post-script in the CareFirst Conversion Case}

The Maryland Insurance Commissioner, Stephen Larsen, initiated hearings on CareFirst's conversion petition prior to the insurance commissioners in the District of Columbia and Delaware. As part of the Maryland hearings and in anticipation of formal hearings in DC, a number of consultants were hired to value CareFirst; most of these valuations exceeded Wellpoint's offer of $\$ 1.3$ billion. In the course of the hearings, there were also concerns raised about the process used by the board of CareFirst to solicit bids and the board's selection of the Wellpoint offer. Finally, the terms of the deal appeared to personally enrich CareFirst executives.

On March 5, 2003, Commissioner Larson denied the petition by CareFirst to convert and to be acquired by Wellpoint. Both the District of Columbia and Delaware suspended their conversion proceedings. In reviewing the research and evidence, Commissioner Larson found three reasons to deny the conversion. First he found that CareFirst had been operating like a forprofit company despite legal requirements to adhere to a non-profit, public-interest mission. Second, he found that the CareFirst board failed to consider CareFirst's obligations as a nonprofit entity and that the Board did not negotiate the best price for CareFirst and was offering to sell at less than fair market value. Third, and finally, Commissioner Larson found that CareFirst did not demonstrate a need to convert to for-profit status in order to remain viable. 
On April 8, 2003, the Maryland legislature ratified Larsen's decision and passed Senate Bill 772. The bill is in essence, an attempt to restructure CareFirst as a well-functioning nonprofit health plan that will execute its mission. It calls for replacement of all Marylandappointed CareFirst board members, compensation paid to board members, officers and employees to be consistent with similar non-profit organizations, establishes a Joint Nonprofit Health Service Plan oversight Committee to oversee CareFirst operations in a manner consistent with the interests of Maryland citizens, and prohibits the acquisition of CareFirst for 5 years. In terms of health plan conduct, it requires that CareFirst to: 1) offer health care products in the individual and small group markets, 2) administer and subsidize the Senior Prescription Drug Program in Maryland, and 3) devote any remaining avoided taxes to a public interest project.

Far from closing the chapter on CareFirst's petition to convert, the Maryland legislation sparked controversy in the District of Columbia and action by some of the parties. The D.C. Commissioner claimed that the Maryland legislation could render the CareFirst plan in D.C. uncompetitive and not viable. The Blue Cross and Blue Shield Association revoked CareFirst's use of the BCBS brand. Finally, Wellpoint abandoned hopes of acquiring CareFirst and announced a deal to acquire the publicly traded holding company of BCBS of Wisconsin.

\section{Summary and Suggestions for Future Research}

The health insurance industry has undergone substantial consolidation in recent years. This consolidation has coincided with, and in part been caused by, the growth of for-profit, publicly traded health insurance companies. These changes in health insurance markets have led industry and government leaders to question the current and potential role of non-profit health plans. Some of these leaders believe that many, if not all, non-profit health plans are already conducting themselves like their for-profit competitors and hence question the value of giving a 
tax exemption to these plans. However, among people holding this view, there is little agreement about what should be done when these non-profit health plans apply to convert to forprofit public stock companies. The lack of agreement derives from uncertainty about the viability of non-profit health plans in a market dominated by for-profit plans and from ignorance about governance structures that could hold non-profit health plans (or foundations) accountable to a public interest mission.

The governance structures necessary to consistently implement a public interest mission, and the viability of a non-profit health plan executing such a mission, form the foundation upon which the welfare consequences of potential changes in conduct of a converting health plan should be evaluated. The welfare consequences of conduct changes must be evaluated in conjunction with the set of feasible alternative institutions for executing the public-interest mission. For example, it may well be that a converting health plan would abandon unprofitable markets and raise premiums in other markets. However, denying the petition to convert does not ensure that unprofitable markets will be better served or that premium increases will be limited to cost increases; furthermore, it does not ensure that the non-profit plan will survive or otherwise be financially capable of these tasks.

Health policymakers are in need of economic research to answer a few basic questions. First, how might unregulated market competition thwart a non-profit health plan in executing its mission? In other words, what are the threats to viability? Second, what market interventions might ensure viability of the mission? Only after these questions are answered can one then pose the social value question: Is the mission worth it? To answer this question, economists and others will have to assess the costs and benefits of alternative regulatory institutions. Finally, creating a conducive environment for a non-profit health plan is not sufficient. Policymakers 
need empirical and theoretical research on the types of governance structures that will guide faithful execution of the non-profit health plan's mission.

While research and experience have identified important gaps in our knowledge, economic analyses have made valuable contributions to the evaluation of conversions. The case study analysis of CareFirst confirms prior research findings that there are differences in health plan quality related to ownership structure. To enhance the usefulness of these findings, we need to understand the causal mechanisms underlying the correlation between quality and health plan characteristics. We do not know for instance whether non-profit plans have higher quality on average because they consider this part of their mission and allocate surplus to achieve this higher quality, or because the organization of non-profit health plans differs from for-profit health plans in ways that facilitate higher quality at the same cost. These are of course not the only two possible explanations and further research is needed to identify and articulate the mechanisms by which health plans influence quality.

The analyses of scale economies presented in this chapter have generated evidence of the relationship between health plan size and average costs. In the case of CareFirst, with over 3.1 million members, there appears to be little or no cost-savings to be achieved through expanded enrollment. This finding calls into question CareFirst's claim that it needs greater access to capital in order to finance future health plan acquisitions.

Finally, the market structure analyses demonstrate the importance of examining distinct product and consumer market segments. Market share analyses for the District of Columbia suggest that the CareFirst plan, GHMSI, possesses substantial market power in some segments. Whether GHMSI was exercising self-restraint in pricing the policies it sold in this market was not possible to determine from the available data. Note that health plan costs by product would 
be necessary to assess price cost margins, and that cost data for every product would be necessary to evaluate a health plan's strategy to cross-subsidize.

The findings presented in this study are subject to a number of caveats and limitations. First, because of its limited scope, there are several health policy issues not addressed by this study. For example, this study did not address the participation by non-profit health plans in traditionally underserved markets. In addition, lack of data prohibited a careful examination of health plan underwriting practices and health plan - provider relationships. Second, it was beyond the scope of the CareFirst case study to examine the extent to which CareFirst was fulfilling its mission, the long-term viability of such a mission, and the governance structures that would facilitate implementation of this mission. ${ }^{19}$ More generally, this case study analysis highlights the need for research elucidating the characteristics of markets that influence the viability of non-profit health plans and scope for welfare improving market interventions. Finally, I began this chapter by noting that every conversion petition is unique; the analyses of CareFirst, the mid-Atlantic markets in which it operates, and the arguments in support of against conversion will not necessarily generalize to health plans petitioning conversion in other markets. However, the framework exposited in this chapter is entirely general, and I hope, will make a contribution to those charged with the challenging tasks of analyzing and evaluating the complex public policy issues surrounding health plan conversions.

\footnotetext{
${ }^{19}$ I was originally hired as a consultant by D.C. Appleseeds to examine the potential consequences of CareFirst converting to stock ownership and being acquired by Wellpoint. It was not until the formal conversion proceedings were well underway that it became clear to me that issues of viability and governance structures would play a central role in the decision calculus of policymakers and regulatory officials.
} 
Figure 1: HMO Enrollment by Tax Status

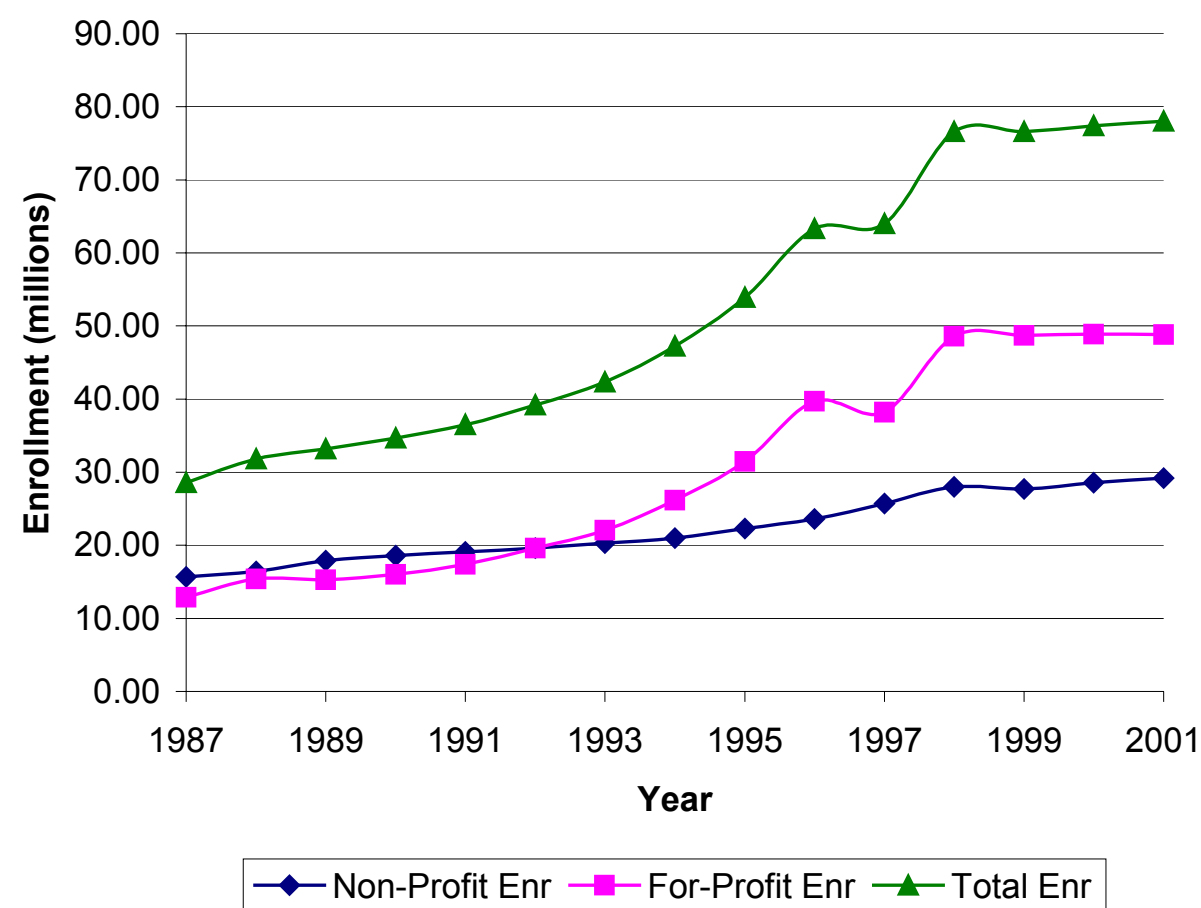

Figure 2: HMO Enrollment in National versus Local or Regional For-Profit Health Plans

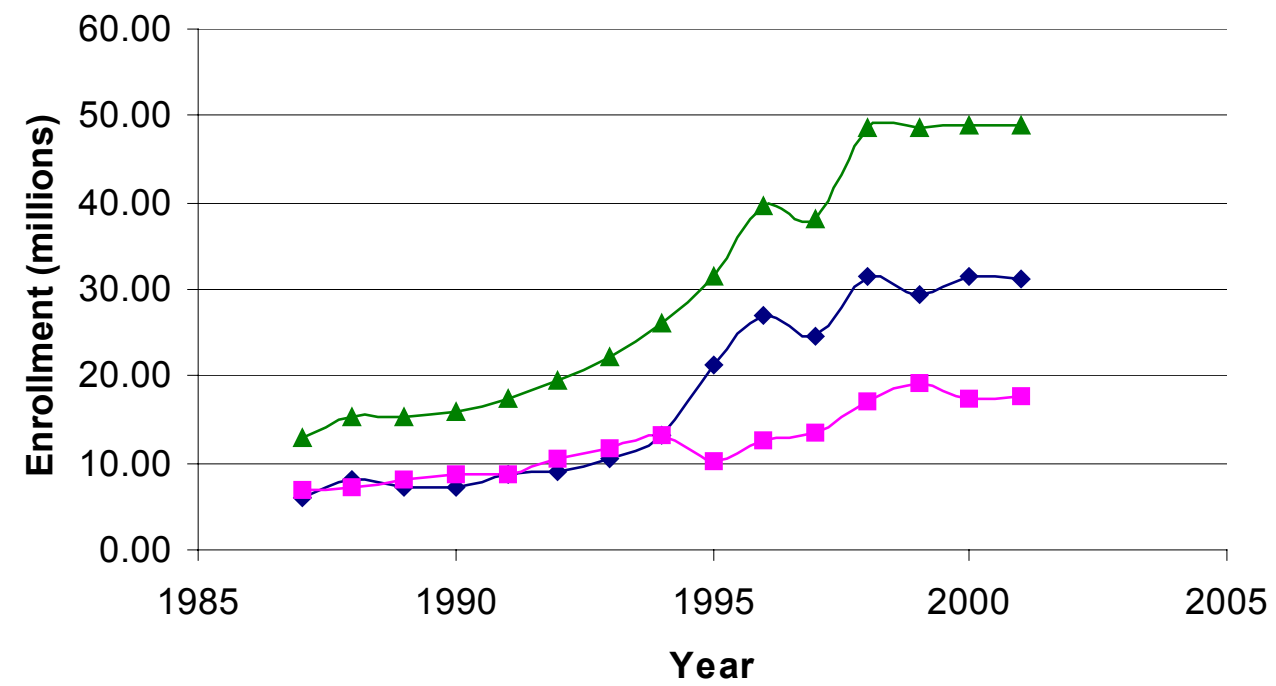

$\multimap-$ For-Profit Nat'I $\rightarrow$ For-Profit Loc/Reg $\longrightarrow$ Total For-Profit Enr 
Figure 3: Decision Calculus for Conversions

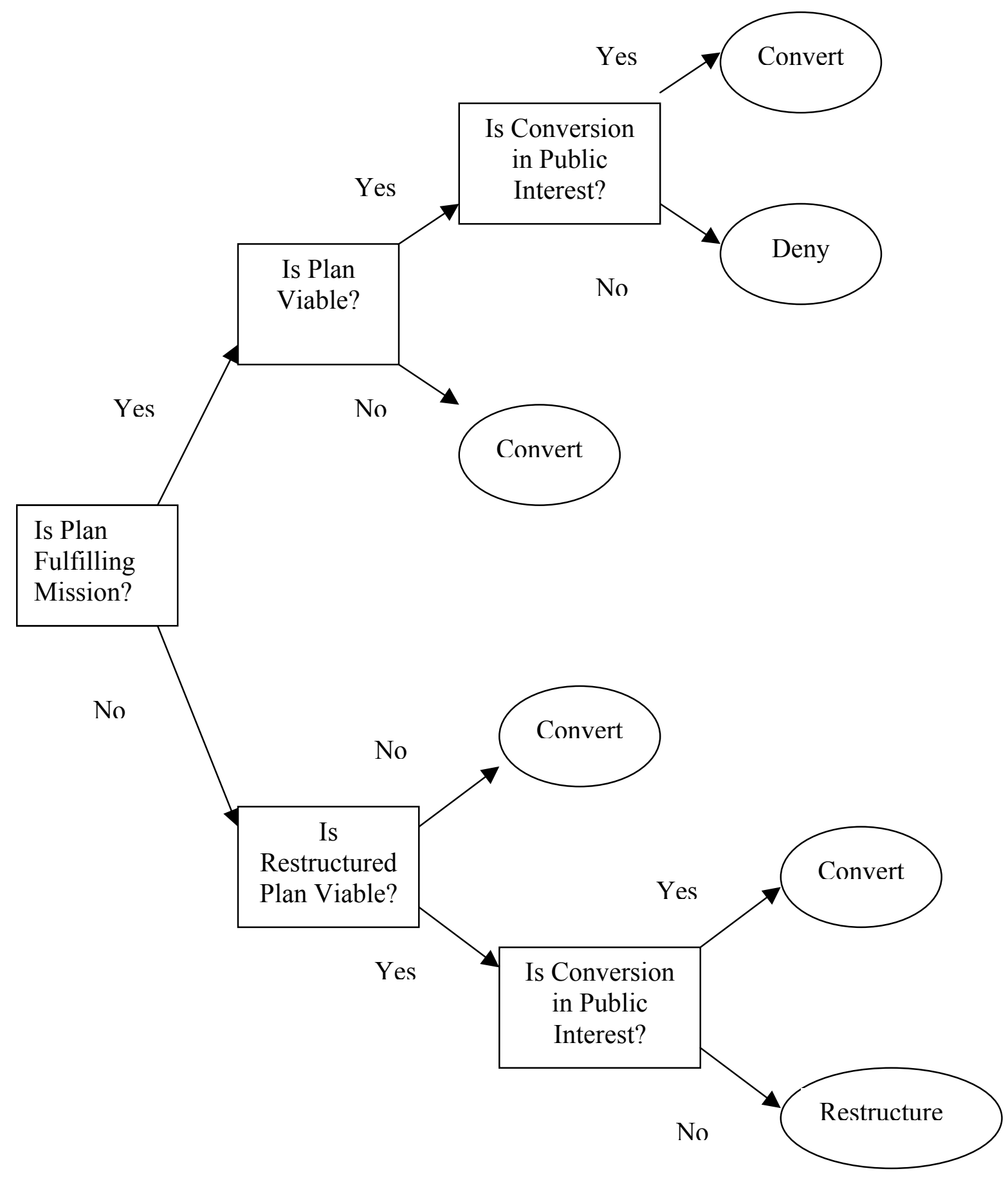


Figure 4:

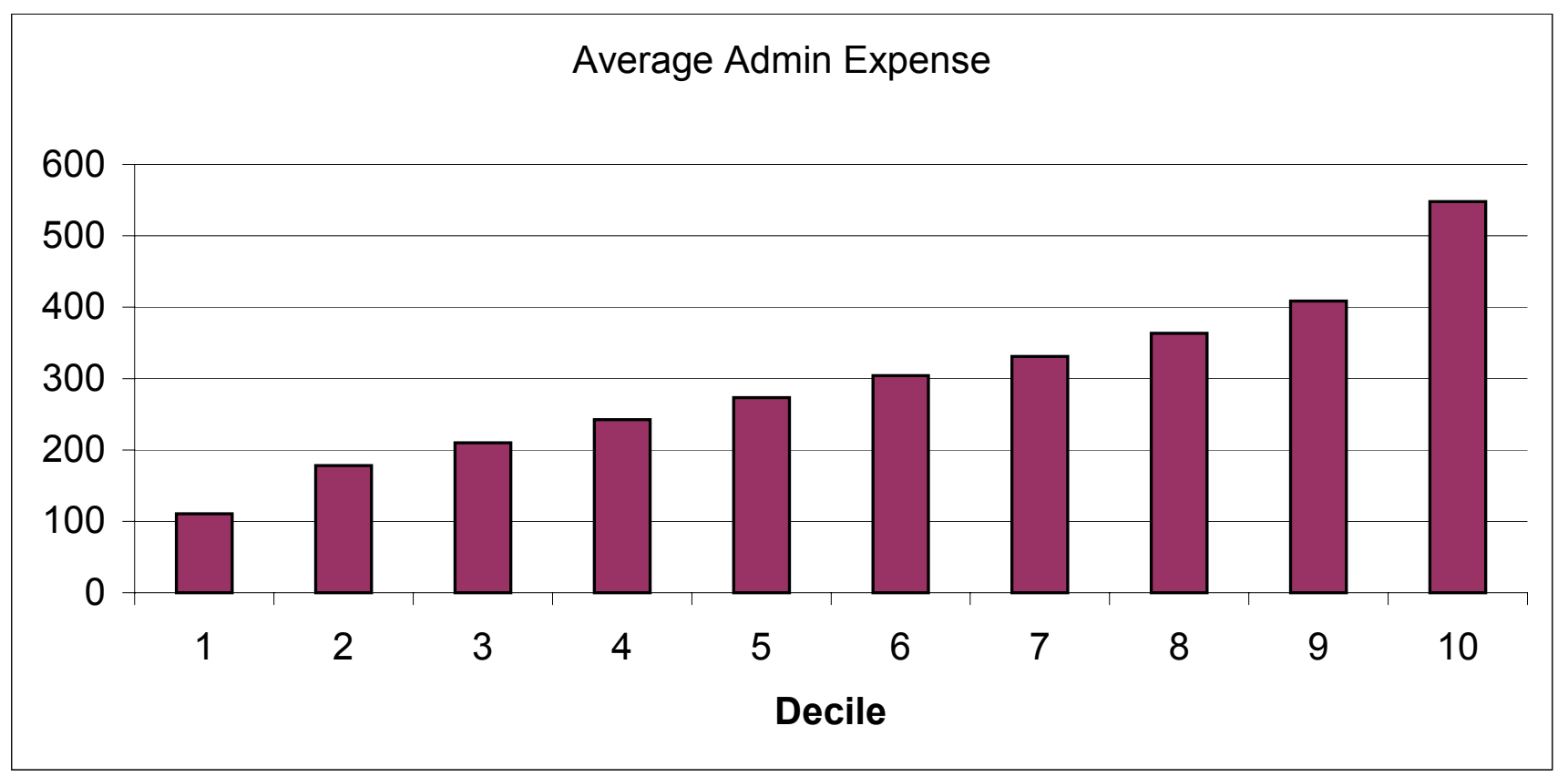

Figure 5:

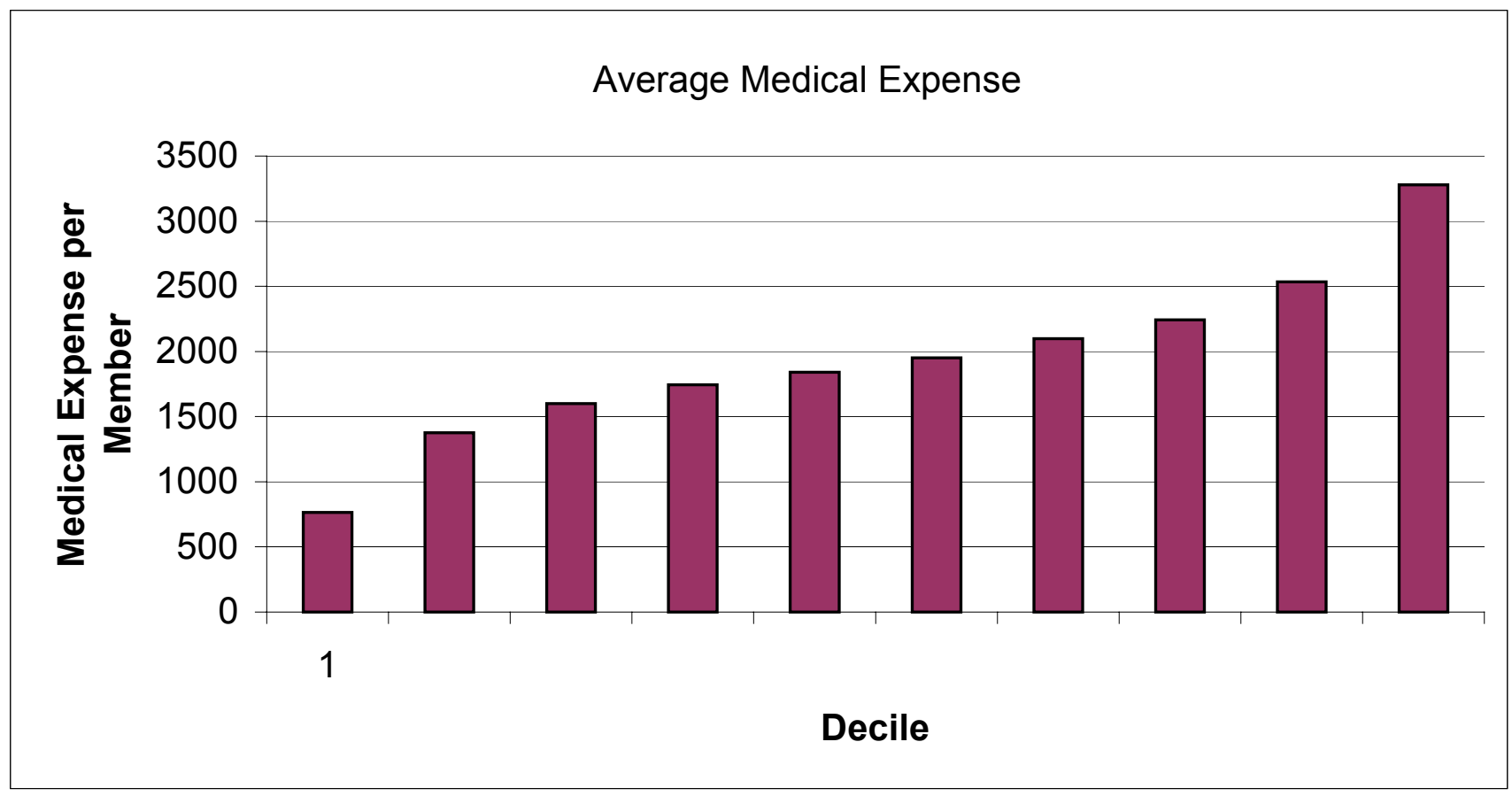


Figure 6: Frequency Distribution of Health Plan Enrollment

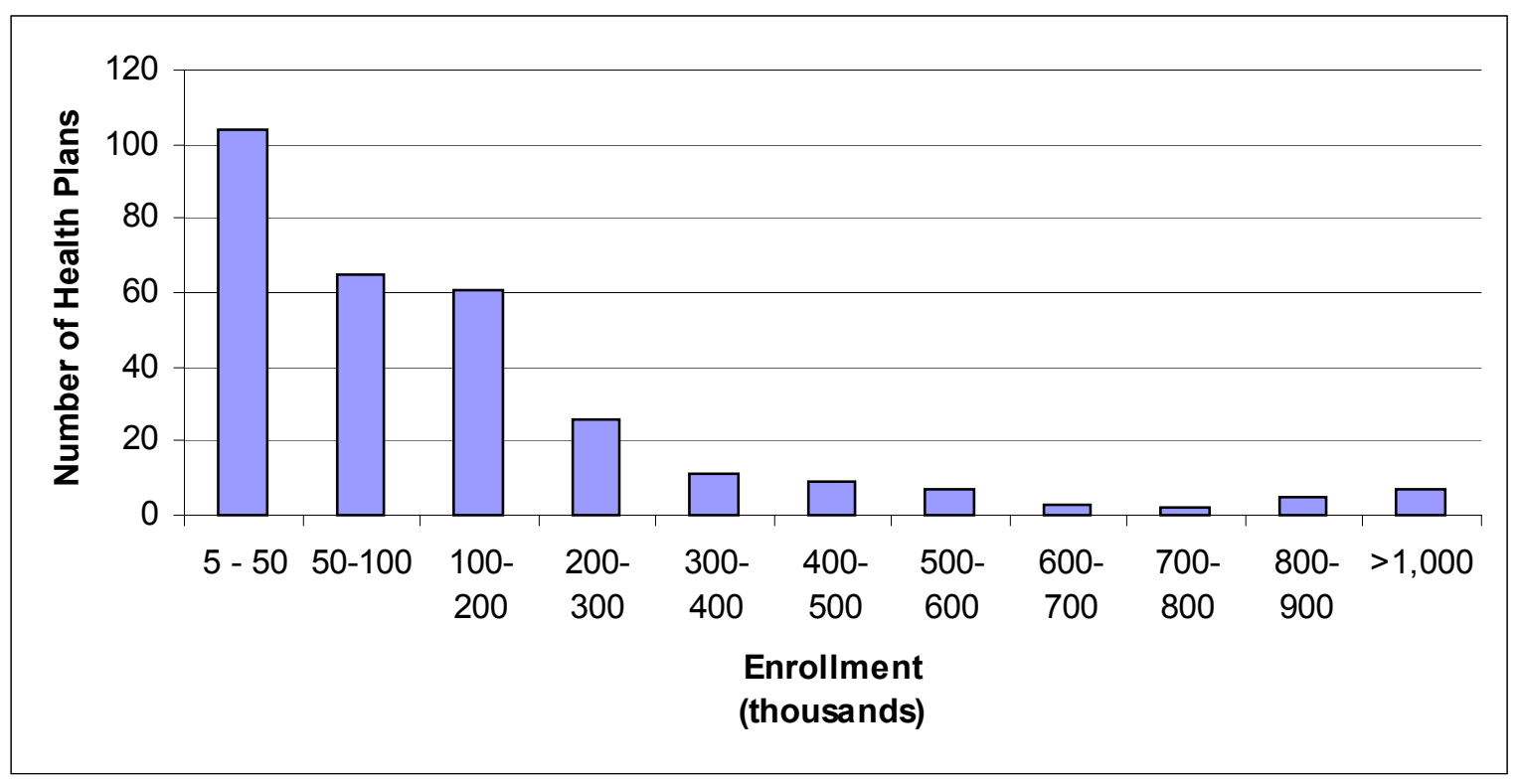

Figure 7:

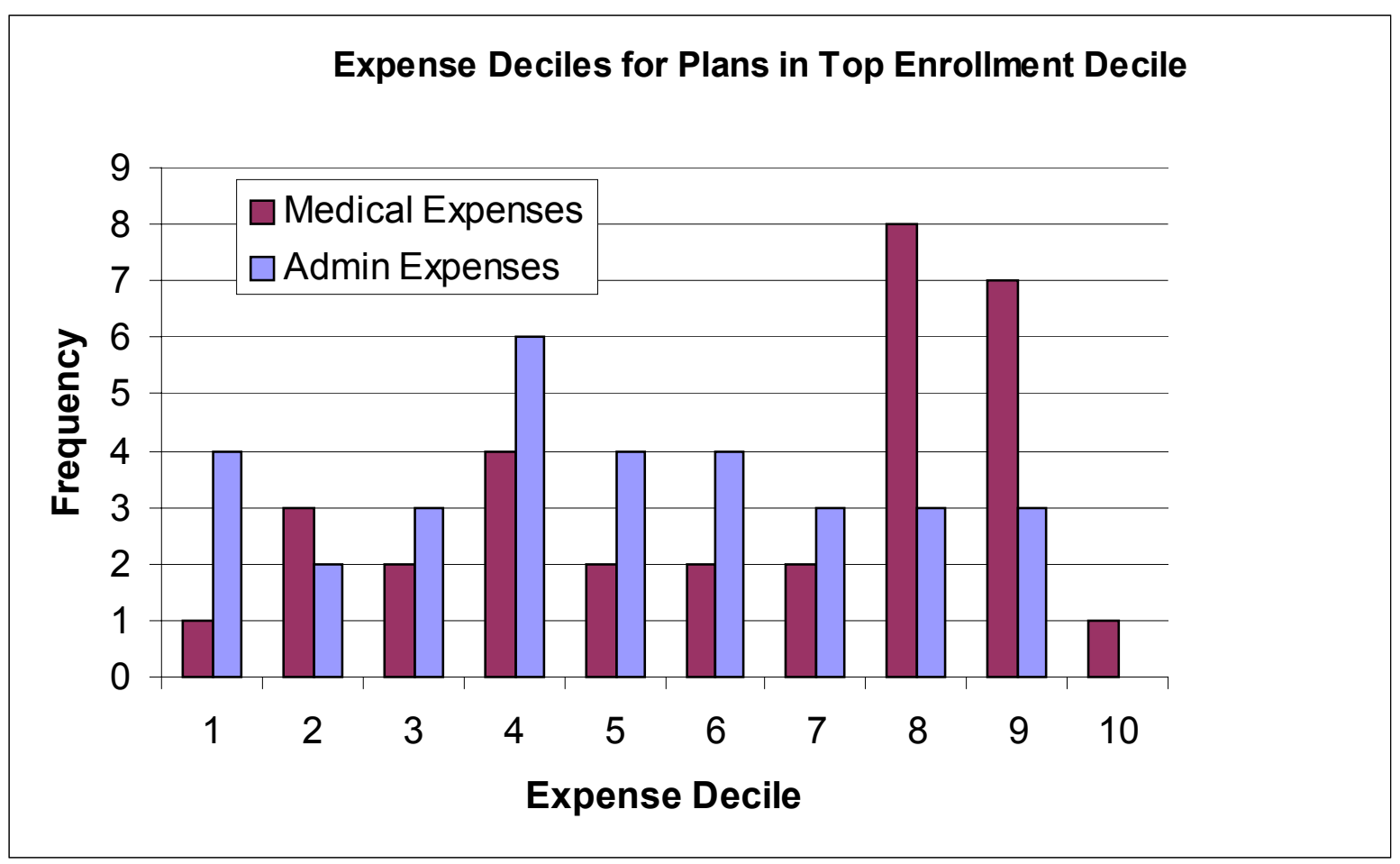


Figure 8:

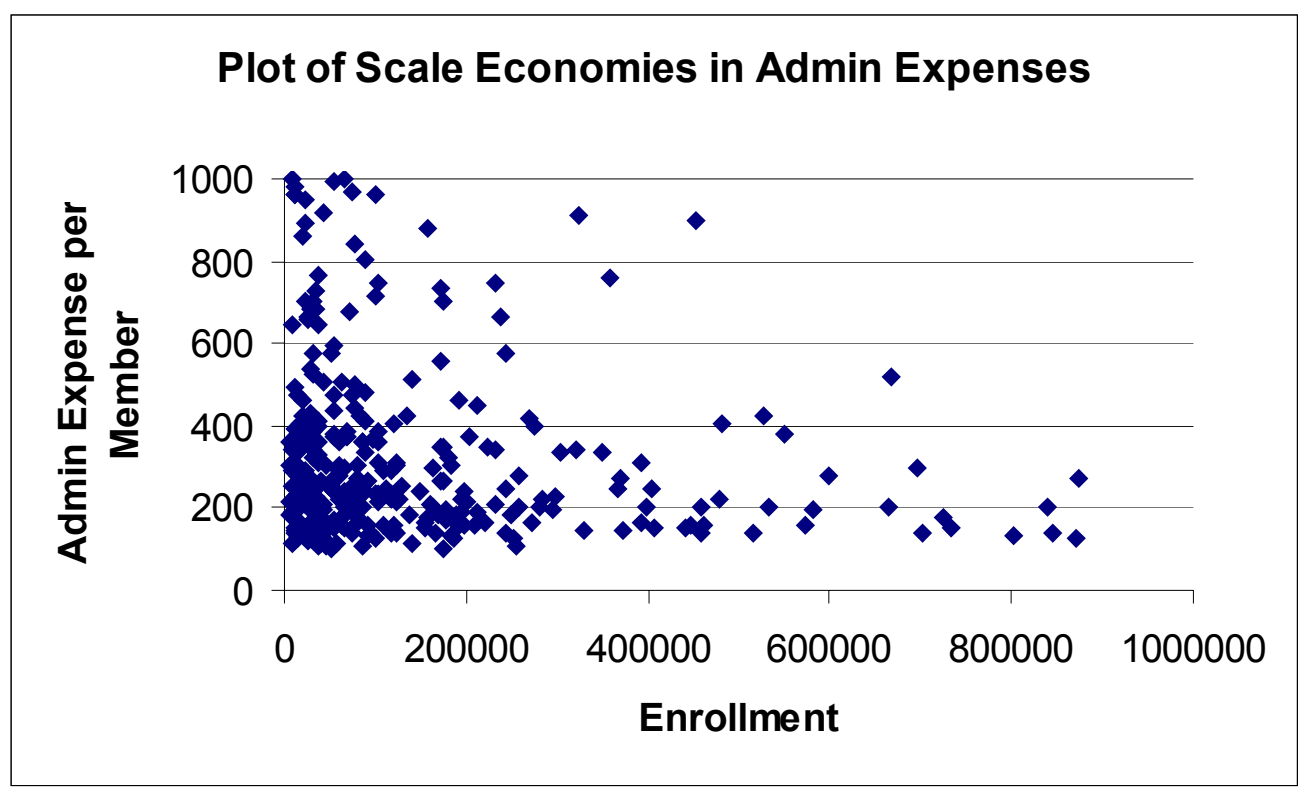

Figure 9:

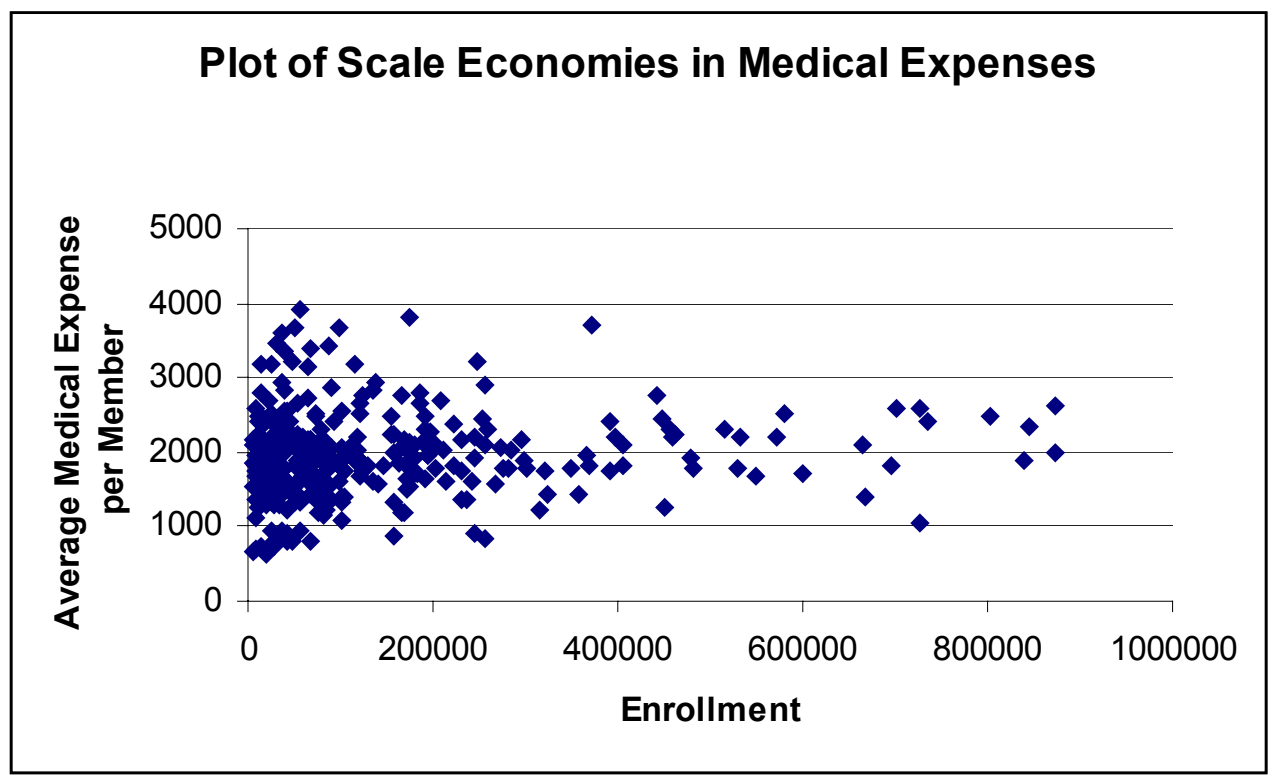


Figure 10: Estimated Scale Economies in Administrative Expenditures

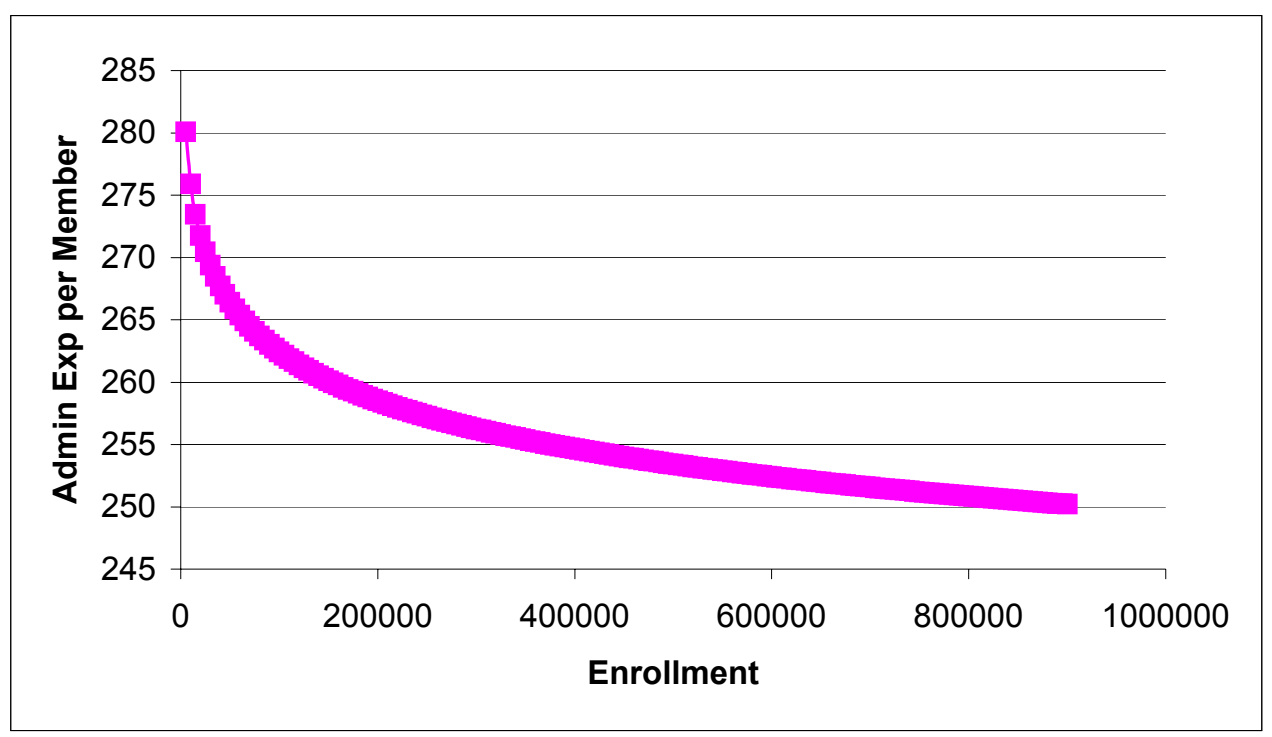

Figure 11: Estimated Scale Economies in Medical Expenses

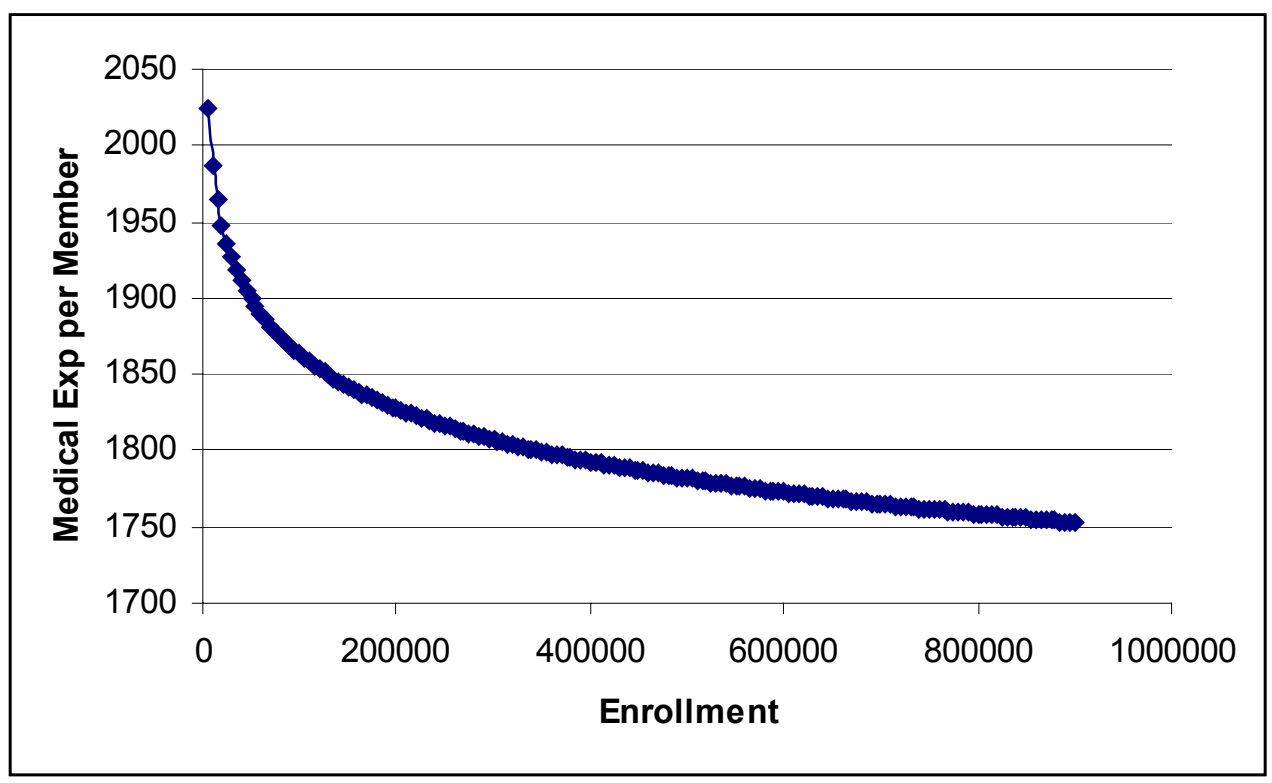


Table 1: Health Plan Enrollment in the District of Columbia, 2000-2001

\begin{tabular}{|l|r|r|r|r|}
\hline & 2001 & & 2000 & \\
\hline & Enroll & Share & Enroll & Share \\
\hline Advantage Healthplan & 3194 & 0.00 & 3471 & 0.00 \\
\hline Aetna U.S. Healthcare (a Maryland corporation) & 177820 & 0.09 & 179469 & 0.10 \\
\hline AMERIGROUP Maryland, Inc. & 12876 & 0.01 & 12640 & 0.01 \\
\hline Capital Community Health Plan & 28851 & 0.02 & 25955 & 0.01 \\
\hline CareFirst BlueChoice Inc. & 46534 & 0.02 & 46525 & 0.03 \\
\hline Cigna Healthcare Mid-Atlantic, Inc. & 1655 & 0.00 & 2146 & 0.00 \\
\hline DC Chartered Health Plan, Inc. & 26877 & 0.01 & 27687 & 0.01 \\
\hline GHMSI & 924798 & 0.48 & 879338 & 0.47 \\
\hline GW University Health Plan & 82854 & 0.04 & 100980 & 0.05 \\
\hline Health Right, Inc. & 9168 & 0.00 & 4838 & 0.00 \\
\hline Kaiser of the Mid-Atlantic & 376877 & 0.20 & 389349 & 0.21 \\
\hline MD - IPA, Inc. & 171207 & 0.09 & 130064 & 0.07 \\
\hline Optimum Choice & 44233 & 0.02 & 25612 & 0.01 \\
\hline Prudential Health Care Plan, Inc. & 0 & 0.00 & 23918 & 0.01 \\
\hline United Healthcare of the Mid-Atlantic, Inc. & 1279 & 0.00 & 1648 & 0.00 \\
\hline & & & & \\
\hline TOTAL & 1908223 & & 1853640 & \\
\hline Herfindahl & & 0.29 & & 0.29 \\
\hline
\end{tabular}


Table 2: Health Plan Enrollment in DC by Consumer Segment, 2001

\begin{tabular}{|c|c|c|c|c|c|c|c|c|}
\hline & group & indiv & medicare & medicaid & $\begin{array}{l}\text { Supplemental } \\
\text { Medicare }\end{array}$ & other & FEHBP & TOTAL \\
\hline $\begin{array}{l}\text { Advantage } \\
\text { Healthplan }\end{array}$ & & 98 & & 3096 & & & & 3194 \\
\hline $\begin{array}{l}\text { Aetna U.S. } \\
\text { Healthcare }\end{array}$ & 36976 & 69 & & & & & 140775 & 177820 \\
\hline $\begin{array}{l}\text { AMERIGROUP } \\
\text { Maryland, Inc. }\end{array}$ & & & & 12876 & & & & 12876 \\
\hline $\begin{array}{l}\text { Capital } \\
\text { Community } \\
\text { Health Plan }\end{array}$ & & & & 28851 & & & & 28851 \\
\hline $\begin{array}{l}\text { CareFirst } \\
\text { BlueChoice Inc. }\end{array}$ & 39708 & 417 & & & & & 6409 & 46534 \\
\hline $\begin{array}{l}\text { Cigna } \\
\text { Healthcare Mid- } \\
\text { Atlantic, Inc. }\end{array}$ & 1654 & 1 & & & & & & 1655 \\
\hline $\begin{array}{l}\text { DC Chartered } \\
\text { Health Plan, } \\
\text { Inc. }\end{array}$ & 78 & 5 & & 26794 & & & & 26877 \\
\hline GHMSI & 422462 & 6804 & & & 2295 & 58519 & 434718 & 924798 \\
\hline $\begin{array}{l}\text { GW University } \\
\text { Health Plan }\end{array}$ & 49034 & 719 & & & & & 33101 & 82854 \\
\hline $\begin{array}{l}\text { Health Right, } \\
\text { Inc. }\end{array}$ & & & & 9168 & & & & 9168 \\
\hline $\begin{array}{l}\text { Kaiser of the } \\
\text { Mid-Atlantic }\end{array}$ & 218288 & 1388 & 7957 & & & 3106 & 146138 & 376877 \\
\hline MD - IPA, Inc. & 90975 & & & & & & 80232 & 171207 \\
\hline $\begin{array}{l}\text { Optimum } \\
\text { Choice }\end{array}$ & 44233 & & & & & & & 44233 \\
\hline $\begin{array}{l}\text { Prudential } \\
\text { Health Care } \\
\text { Plan, Inc. }\end{array}$ & & & & & & & & 0 \\
\hline $\begin{array}{l}\text { United } \\
\text { Healthcare of } \\
\text { the Mid- } \\
\text { Atlantic }\end{array}$ & 1279 & & & & & & & 1279 \\
\hline TOTAL & 904687 & 9501 & 7957 & 80785 & 2295 & 61625 & 841373 & 1908223 \\
\hline
\end{tabular}


Table 3: Total Health Plan Enrollment in 2001, by product type ${ }^{20}$

\begin{tabular}{|l|r|l|l|r|r|}
\hline & HMO & PPO & POS & Indemnity & TOTAL \\
\hline $\begin{array}{l}\text { Kaiser Foundation Health } \\
\text { Plan }\end{array}$ & 501088 & & & & \\
\hline Prudential Health Care Plan & 0 & & & & 515948 \\
\hline Health Right, Inc. & 9168 & & & & 0 \\
\hline Optimum Choice, Inc. & 392153 & & & & 392153 \\
\hline $\begin{array}{l}\text { MD-Individual Practice } \\
\text { Assoc, Inc. }\end{array}$ & 122860 & & & & \\
\hline DC Chartered Health Plan & 26877 & & & & 122860 \\
\hline United Healthcare & 180478 & & & & 180478 \\
\hline $\begin{array}{l}\text { Capital Community Health } \\
\text { Plan }\end{array}$ & 28085 & & & & \\
\hline Amerigroup Maryland, Inc. & 131430 & & & & 131430 \\
\hline Aetna U.S. Healthcare, Inc. & 369004 & & 36396 & & 405400 \\
\hline Cigna Healthcare & 32589 & & 4485 & & 37074 \\
\hline GW University Health Plan & 59545 & & 3882 & & 63427 \\
\hline CareFirst BlueChoice & 123372 & & 45572 & & 168944 \\
\hline GHMSI & & 589251 & 85058 & 38232 & 712541 \\
\hline Advantage Healthplan, Inc. & 3194 & & & & 3194 \\
\hline & & & & & \\
\hline TOTAL & 1979843 & 589251 & 190253 & 38232 & 2797579 \\
\hline
\end{tabular}

Table 4: Herfindahl Statistics and GHMSI Market Share for Market Segments, 2001

\begin{tabular}{|l|l|l|}
\hline Market Segment & Herfindahl & $\begin{array}{l}\text { GHMSI } \\
\text { Market Share }\end{array}$ \\
\hline Commercial Group & 0.30 & 0.47 \\
\hline FEHBP & 0.34 & 0.52 \\
\hline Individual & 0.54 & 0.72 \\
\hline Medicare Supplemental & 1.00 & 1.00 \\
\hline PPO & 1.00 & 1.00 \\
\hline POS ${ }^{21}$ & 0.30 & 0.45 \\
\hline Indemnity & 1.00 & 1.00 \\
\hline & & \\
\hline
\end{tabular}

\footnotetext{
${ }^{20}$ Total health plan enrollment excluding FEHBP enrollment.

${ }^{21}$ Because enrollment by product type is only reported at the health plan level for the entire DC-MD-VA market area, the Herfindal and GHMSI market share statistics are difficult to interpret. It is possible that there are managed care companies offering POS products in Maryland and Virginia but not in the District of Columbia. This would cause the Herfindahl and GHMSI market share statistics in Table 1.7 to overstate the true measures. However, it could also be that in the District, GHMSI is the only health plan offering a POS product, in which case the reported Herfindahl and GHMSI market share would understand the true measures.
} 
Table 5: 1999-2001 Changes in Enrollment by Product Type in the DC-MD-VA Region

\begin{tabular}{|c|c|c|c|c|c|c|}
\hline & \multicolumn{6}{|c|}{ Enrollment Change: 1999-2001 } \\
\hline & $\begin{array}{r}\text { TOTAL } \\
\text { Enrollment }\end{array}$ & $\begin{array}{r}\text { National } \\
\text { For- } \\
\text { Profit }\end{array}$ & $\begin{array}{r}\text { VA- } \\
\text { BCBS }\end{array}$ & Independent & CareFirst & TOTAL \\
\hline $\begin{array}{l}\text { Commercial } \\
\text { HMO }\end{array}$ & 1759586 & -419530 & 28726 & -58556 & 34899 & -471913 \\
\hline PPO & 645149 & 101435 & 0 & -1011 & 355443 & 455867 \\
\hline FEHBP & 463346 & -13142 & 1746 & 15714 & -7055 & -2737 \\
\hline Public & 455393 & 45075 & 27128 & -3425 & -125900 & -57122 \\
\hline Self & 434079 & -137959 & 0 & -14897 & 202671 & 49815 \\
\hline $\begin{array}{l}\text { Open-Panel } \\
\text { HMO }\end{array}$ & 382013 & -111823 & $\begin{array}{r}- \\
10017\end{array}$ & -3728 & -84608 & -210176 \\
\hline $\begin{array}{l}\text { Other non- } \\
\text { HMO }\end{array}$ & 275474 & 245378 & 0 & 26306 & 0 & 271684 \\
\hline POS & 146220 & -45365 & 0 & 0 & 0 & -45365 \\
\hline Direct & 62587 & -9927 & -3224 & -2445 & -750 & -16346 \\
\hline FFS & 0 & 0 & 0 & 0 & 0 & 0 \\
\hline Supplemental & 0 & 0 & 0 & 0 & 0 & 0 \\
\hline $\begin{array}{l}\text { TOTAL } \\
\text { Managed } \\
\text { Care }\end{array}$ & 4626062 & -345887 & 13093 & -42759 & 374700 & -27039 \\
\hline
\end{tabular}


Table 6: Enrollment Changes Nationwide, 1999-2001

\begin{tabular}{|c|c|c|c|c|c|c|}
\hline & 2001 & Enrollmer & Change: 1 & $\begin{array}{l}001 \\
\quad(\mathbf{0 0 0})\end{array}$ & & \\
\hline & $\begin{array}{r}\text { TOTAL } \\
\text { Enrollment } \\
(000)\end{array}$ & $\begin{array}{r}\text { National } \\
\text { Managed } \\
\text { Care }\end{array}$ & $\begin{array}{r}\text { Not-For } \\
\text { Profit } \\
\text { BCBS }\end{array}$ & $\begin{array}{r}\text { For Profit } \\
\text { BCBS }\end{array}$ & Independent & TOTAL \\
\hline Commercial Group HMO & 46722 & -4429 & 73 & 1384 & -1172 & -4144 \\
\hline PPO & 36324 & 4376 & 817 & 6917 & 2289 & 14399 \\
\hline FEHBP & 2362 & -114 & 128 & 20 & 63 & 97 \\
\hline Public Programs & 17746 & -581 & 1295 & -1002 & 1174 & 886 \\
\hline Self-Insured & 6759 & -98 & 749 & 697 & -280 & 1068 \\
\hline Open-ended HMO & 8563 & -164 & 14 & 257 & -381 & -273 \\
\hline Other non-HMO & 6879 & 3108 & 575 & 115 & 427 & 4225 \\
\hline POS & 6637 & -895 & -423 & -1640 & 111 & -2848 \\
\hline Direct Pay & 1562 & -256 & 114 & -213 & -121 & -475 \\
\hline Managed FFS & 2334 & -79 & -107 & 900 & 309 & 1023 \\
\hline Supplemental Medicare & 1040 & -21 & 305 & 445 & 73 & 803 \\
\hline $\begin{array}{l}\text { TOTAL } \\
\text { Managed Care }\end{array}$ & 137998 & 858 & 3631 & 7917 & 2619 & 15025 \\
\hline
\end{tabular}


Table 7: Scale Economies - Regression Results

\begin{tabular}{|c|c|c|}
\hline Independent Variable & $\begin{array}{c}(2) \\
\text { Dep Var } \\
\text { Log (Admin Exp per } \\
\text { Mem) }\end{array}$ & $\begin{array}{c}(3) \\
\text { Dep Var } \\
\text { Log (Med Exp per } \\
\text { Mem) }\end{array}$ \\
\hline \% Enroll Share - Medicare Risk & $\begin{array}{r}1.54 \\
(0.22) \\
\end{array}$ & $\begin{array}{r}1.18 \\
(0.26) \\
\end{array}$ \\
\hline \% Enroll share -Medicaid Risk & $\begin{array}{r}-0.28 \\
(0.16) \\
\end{array}$ & $\begin{array}{r}-0.27 \\
(0.18)\end{array}$ \\
\hline \% Enroll share - Direct Pay & $\begin{array}{r}0.07 \\
(0.41)\end{array}$ & $\begin{array}{r}-0.83 \\
(0.28) \\
\end{array}$ \\
\hline \% Enroll Share - FEHBP & $\begin{array}{r}-0.25 \\
(0.45)\end{array}$ & $\begin{array}{r}0.14 \\
(0.34)\end{array}$ \\
\hline \% Enroll Share - Commercial HMO & $\begin{array}{r}-0.16 \\
(0.14)\end{array}$ & $\begin{array}{r}-0.30 \\
(0.20)\end{array}$ \\
\hline$\%$ Enroll Share - POS & $\begin{array}{r}0.74 \\
(0.21)\end{array}$ & $\begin{array}{r}0.44 \\
(0.22)\end{array}$ \\
\hline$\%$ Enroll Share - PPO & $\begin{array}{r}0.04 \\
(0.14)\end{array}$ & $\begin{array}{r}-0.56 \\
(0.29)\end{array}$ \\
\hline $\begin{array}{l}\text { \% Enroll Share - Supplemental } \\
\text { Medicare }\end{array}$ & $\begin{array}{r}2.36 \\
(1.75)\end{array}$ & $\begin{array}{r}0.85 \\
(0.97)\end{array}$ \\
\hline$\%$ Enroll share - FFS & $\begin{array}{r}0.65 \\
(0.55)\end{array}$ & $\begin{array}{r}-0.29 \\
(0.41)\end{array}$ \\
\hline$\%$ Provider Payment - Capitation & $\begin{array}{r}-0.12 \\
(0.14)\end{array}$ & $\begin{array}{r}-0.12 \\
(0.12)\end{array}$ \\
\hline $\begin{array}{l}\text { \% Provider Payment }- \text { Fee For } \\
\text { Service }\end{array}$ & $\begin{array}{r}0.05 \\
(0.09)\end{array}$ & $\begin{array}{r}-0.03 \\
(0.13)\end{array}$ \\
\hline Provider Payment Imputation & $\begin{array}{r}-0.31 \\
(0.19)\end{array}$ & $\begin{array}{r}0.28 \\
(0.24)\end{array}$ \\
\hline Product Herfindahl & $\begin{array}{r}0.12 \\
(0.18)\end{array}$ & $\begin{array}{r}0.31 \\
(0.20)\end{array}$ \\
\hline Age of Plan & $\begin{array}{r}0.00 \\
(0.00)\end{array}$ & $\begin{array}{r}0.00 \\
(0.00)\end{array}$ \\
\hline Physicians per 1000 Enrollees & $\begin{array}{r}475.34 \\
(152.54)\end{array}$ & $\begin{aligned}-796.89 \\
(208.74)\end{aligned}$ \\
\hline Log of Enrollment & $\begin{array}{r}-0.05 \\
(0.03)\end{array}$ & $\begin{array}{r}-0.64 \\
(0.03)\end{array}$ \\
\hline $\begin{array}{l}\text { Log of National Managed Care } \\
\text { Enrollment }\end{array}$ & $\begin{array}{r}-0.00 \\
(0.01)\end{array}$ & $\begin{array}{r}0.00 \\
(0.00)\end{array}$ \\
\hline $\begin{array}{l}\text { Log of Regional Managed Care } \\
\text { Enrollment }\end{array}$ & $\begin{array}{r}0.00 \\
(0.01)\end{array}$ & $\begin{array}{r}-0.01 \\
(0.01)\end{array}$ \\
\hline For-Profit HMO & $\begin{array}{r}0.16 \\
(0.08)\end{array}$ & $\begin{array}{r}-0.01 \\
(0.06)\end{array}$ \\
\hline $\begin{array}{l}\% \text { of enrollment in IPA or Mixed } \\
\text { Model }\end{array}$ & $\begin{array}{r}0.14 \\
(0.06)\end{array}$ & $\begin{array}{r}0.13 \\
(0.06)\end{array}$ \\
\hline
\end{tabular}




\begin{tabular}{|l|r|r|}
\hline Number of Products & 0.00 & 0.07 \\
& $(0.02)$ & $(0.02)$ \\
\hline Number of States & 0.13 & 0.15 \\
& $(0.11)$ & $(0.14)$ \\
\hline Constant & 5.82 & 7.85 \\
& $(0.29)$ & $(0.29)$ \\
\hline State Dummy Variables & Included & Included \\
\hline Number of Observations & 299 & 299 \\
\hline R-Squared & 0.50 & 0.54 \\
\hline
\end{tabular}

$* * * \mathrm{P} \leq 0.01$

$* * \quad \mathrm{P} \leq 0.05$

$* \quad \mathrm{P} \leq 0.10$ 
Table 8: Comparison of CareFirst \& Wellpoint Plans on HEDIS Measures

\begin{tabular}{|l|r|r|r|r|r|}
\hline HEDIS Measures & $\begin{array}{r}\text { Carefirs } \\
\text { t }\end{array}$ & $\begin{array}{r}\text { BC of } \\
\text { CA }\end{array}$ & National & $\begin{array}{r}\text { National } \\
\text { Public FP }\end{array}$ & $\begin{array}{r}\text { National } \\
\text { Std. Dev. }\end{array}$ \\
\hline Preventive Care & & & & & \\
\hline Child immunization 1 & 77.6 & 68.4 & 65.9 & 65.7 & 13.0 \\
\hline Child immunization 2 & 65.6 & & 48.7 & 47.6 & 11.7 \\
\hline Adol immunization 1 & 24.7 & 27.4 & 33.2 & 28.7 & 17.7 \\
\hline Adol immunization 2 & 16.7 & & 15.6 & 12.4 & 11.9 \\
\hline Advice to quit smoking & 70.1 & 60.8 & 64.7 & 62.3 & 6.9 \\
\hline Breast cancer screening & 70.6 & 75.9 & 74.9 & 72.6 & 5.9 \\
\hline Cervical cancer screening & 68.4 & 70.1 & 73.7 & 71.8 & 7.7 \\
\hline Prenatal care & 85.1 & 87.3 & 86.4 & 86.8 & 11.1 \\
\hline Check-up after delivery & 69.3 & 79.1 & 74.6 & 73.7 & 11.8 \\
\hline Beta blockers & 85.5 & 86.9 & 86.5 & 87.2 & 9.7 \\
\hline Chronic Care & & & & & 47.8 \\
\hline Cholesterol rate & 18.8 & & 47.8 & 45.1 & 15.0 \\
\hline Cholesterol screening & 70.7 & & 70.2 & 67.8 & 11.1 \\
\hline HbAlc test & 79.1 & & 77.3 & 76.3 & 8.9 \\
\hline Diabetic eye exam & 58.8 & 39.5 & 48.5 & 44.7 & 14.3 \\
\hline Lipid profile & 68.0 & & 70.4 & 69.7 & 9.9 \\
\hline Lipid control & 44.8 & & 38.6 & 35.8 & 9.6 \\
\hline Nephropathy monitoring & 38.1 & & 37.3 & 35.7 & 14.4 \\
\hline HbAlc control & 79.7 & & 58.0 & 55.3 & 14.3 \\
\hline Mental Health & & & & & \\
\hline Mental Illness - 7 days & 60.6 & 45.0 & 49.2 & 49.6 & 14.7 \\
\hline Mental Illness - 30 days & 72.0 & 50.5 & 72.3 & 70.9 & 13.7 \\
\hline Depression contact & 8.7 & & 21.3 & 19.9 & 10.3 \\
\hline Depression acute & 68.9 & & 60.3 & 61.3 & 9.5 \\
\hline Depression continuous & 45.2 & & 43.6 & 43.2 & 10.4 \\
\hline & & & & & \\
\hline
\end{tabular}


Table 9: Comparison of BCBS Plans to Kaiser Plans on HEDIS Measures

\begin{tabular}{|c|c|c|c|c|}
\hline & Carefirst & $\begin{array}{r}\text { Kaiser } \\
\text { Mid-Atlantic }\end{array}$ & $\mathrm{BC}$ of $\mathrm{CA}$ & $\begin{array}{r}\text { Kaiser } \\
\text { California }\end{array}$ \\
\hline \multicolumn{5}{|l|}{ Preventive Care } \\
\hline Child immunization 1 & 77.6 & 88.6 & 68.4 & 76.2 \\
\hline Child immunization 2 & 65.6 & 76.5 & & 69.5 \\
\hline Adol immunization 1 & 24.7 & 48.4 & 27.4 & 34.5 \\
\hline Adol immunization 2 & 16.7 & 50.2 & & 16.6 \\
\hline Advice to quit smoking & 70.1 & 67.6 & 60.8 & 68.0 \\
\hline Breast cancer screening & 70.6 & 79.4 & 75.9 & 75.8 \\
\hline Cervical cancer screening & 68.4 & 88.6 & 70.1 & 77.4 \\
\hline Prenatal care & 85.1 & 86.9 & 87.3 & 89.5 \\
\hline Check-up after delivery & 69.3 & 80.1 & 79.1 & 83.2 \\
\hline Beta blockers & 85.5 & 98.3 & 86.9 & 89.7 \\
\hline \multicolumn{5}{|l|}{ Chronic Care } \\
\hline Cholesterol rate & 18.8 & 67.5 & & 45.2 \\
\hline Cholesterol screening & 70.7 & 75.3 & & 78.4 \\
\hline HbA1c test & 79.1 & 85.9 & & 77.5 \\
\hline Diabetic eye exam & 58.8 & 87.7 & 39.5 & 64.0 \\
\hline Lipid profile & 68.0 & 69.2 & & 70.5 \\
\hline Lipid control & 44.8 & 41.9 & & 41.2 \\
\hline Nephropathy monitoring & 38.1 & 74.8 & & 55.2 \\
\hline HbA1c control & 79.7 & 71.1 & & 55.1 \\
\hline \multicolumn{5}{|l|}{ Mental Health Care } \\
\hline Mental Illness -7 days & 60.6 & 65.5 & 45.0 & 62.6 \\
\hline Mental Illness -30 days & 72.0 & 79.2 & 50.5 & 83.3 \\
\hline Depression contact & 8.7 & 34.6 & & 28.4 \\
\hline Depression acute & 68.9 & 63.8 & & 68.6 \\
\hline Depression continuous & 45.2 & 46.1 & & 58.2 \\
\hline
\end{tabular}


Table 10: Comparison of CareFirst and Wellpoint Plans on CAHPS Measures

\begin{tabular}{|l|r|r|r|r|r|}
\hline & Carefirst & $\begin{array}{r}\text { BC of } \\
\text { CA }\end{array}$ & National & $\begin{array}{r}\text { National } \\
\text { Public FP }\end{array}$ & $\begin{array}{r}\text { National } \\
\text { Std. Dev. }\end{array}$ \\
\hline Claims Processing & 83.0 & 81.1 & 79.1 & 76.4 & 9.2 \\
\hline Courteous Staff & 90.7 & 88.8 & 91.6 & 90.7 & 2.7 \\
\hline Customer Service & 66.0 & 64.9 & 65.8 & 63.0 & 6.3 \\
\hline Getting Care Quickly & 78.1 & 67.6 & 79.2 & 77.8 & 5.4 \\
\hline Getting Needed Care & 77.2 & 70.6 & 75.4 & 72.7 & 6.8 \\
\hline $\begin{array}{l}\text { Communication with } \\
\text { doctor }\end{array}$ & 91.2 & 86.2 & 89.8 & 88.9 & 2.9 \\
\hline $\begin{array}{l}\text { Overall Health Care } \\
\text { Rating }\end{array}$ & 68.5 & 68.4 & 71.1 & 68.8 & 6.1 \\
\hline $\begin{array}{l}\text { Overall Health Plan } \\
\text { Rating }\end{array}$ & 59.2 & 56.0 & 58.0 & 53.5 & 8.4 \\
\hline Overall PCP Rating & 74.0 & 74.2 & 73.5 & 73.2 & 4.4 \\
\hline Overall Specialist Ratingt & 75.5 & 67.4 & 75.3 & 74.6 & 4.8 \\
\hline
\end{tabular}

Table 11: Comparison of CareFirst and Wellpoint Plans to Kaiser Plans on CAHPS Measures

\begin{tabular}{|l|r|r|r|r|}
\hline & Carefirst & $\begin{array}{r}\text { Kaiser } \\
\text { Mid-Atlantic }\end{array}$ & BC of CA & $\begin{array}{r}\text { Kaiser } \\
\text { California }\end{array}$ \\
\hline Claims Processing & 83.0 & 66.0 & 81.1 & 79.1 \\
\hline Courteous Staff & 90.7 & 90.5 & 88.8 & 90.3 \\
\hline Customer Service & 66.0 & 77.4 & 64.9 & 73.0 \\
\hline Getting Care Quickly & 78.1 & 80.0 & 67.6 & 76.0 \\
\hline Getting Needed Care & 77.2 & 76.2 & 70.6 & 78.8 \\
\hline Communication with doctor & 91.2 & 82.2 & 86.2 & 87.0 \\
\hline Overall Health Care Rating & 68.5 & 65.2 & 68.4 & 70.3 \\
\hline Overall Health Plan Rating & 59.2 & 57.3 & 56.0 & 64.5 \\
\hline Overall PCP Rating & 74.0 & 72.4 & 74.2 & 75.0 \\
\hline Overall Specialist Rating & 75.5 & 71.3 & 67.4 & 75.3 \\
\hline
\end{tabular}




\section{Exhibit 1: Descriptions of Health Insurance Products as Defined by InterStudy}

\begin{tabular}{|c|c|}
\hline Health Insurance Product & Description \\
\hline Direct Pay Enrollment & $\begin{array}{l}\text { Enrollees are individuals who are not members of a contracting } \\
\text { group (i.e. they are enrolled under an individual coverage } \\
\text { option). }\end{array}$ \\
\hline FEHBP & $\begin{array}{l}\text { Enrollees are federal employees and participate in the Federal } \\
\text { Employees Health Benefits Program }\end{array}$ \\
\hline Commercial Group & $\begin{array}{l}\text { Includes individuals enrolled through employer-sponsored } \\
\text { group HMO policies, as well as conversion members (persons } \\
\text { who are no longer members of an employer group, but under } \\
\text { COBRA regulations, are still eligible for HMO services at a } \\
\text { group rate) }\end{array}$ \\
\hline Public programs & $\begin{array}{l}\text { Recipients of Medicaid and Medicare who are enrolled in an } \\
\text { HMO }\end{array}$ \\
\hline Point of Service (POS) & $\begin{array}{l}\text { Enrollees have access to and financial incentives to use a } \\
\text { managed care provider network, often the HMO's provider } \\
\text { panel, but in contrast to the open-panel HMO, POS enrollees } \\
\text { are not prepaid enrollees of the HMO (they pay indemnity } \\
\text { premiums) }\end{array}$ \\
\hline Open-Ended HMO & $\begin{array}{l}\text { Enrollees are prepaid members of the HMO and may receive } \\
\text { non-emergency services from providers outside the HMO's } \\
\text { network. There is usually a substantial deductible, co-payment } \\
\text { or need for coinsurance for use of non-panel providers }\end{array}$ \\
\hline $\begin{array}{l}\text { Preferred Provider } \\
\text { Organization (PPO) }\end{array}$ & $\begin{array}{l}\text { A fee-for-service product where beneficiaries receive care from } \\
\text { a selected panel of providers. Providers agree to a discounted } \\
\text { fee schedule when contracting with the PPO. PPOs offer a wide } \\
\text { variety of benefit plans, some including the option to use non- } \\
\text { panel providers if beneficiaries pay out-of-pocket costs. }\end{array}$ \\
\hline $\begin{array}{l}\text { Managed Fee For Service } \\
\text { (FFS) }\end{array}$ & $\begin{array}{l}\text { The insurer pays the cost of covered services after services have } \\
\text { been received and according to an agreed upon fee schedule. } \\
\text { Various managed care tools such as pre-certification, second } \\
\text { surgical opinion, and utilization review are used }\end{array}$ \\
\hline Self-Insured & $\begin{array}{l}\text { The HMO providers deliver health services to an individual, but } \\
\text { rather than being prepaid enrollees, or premium paying } \\
\text { beneficiaries, services received are paid for directly by the } \\
\text { enrollee's employer. }\end{array}$ \\
\hline Supplemental Medicare & $\begin{array}{l}\text { A Medicare wrap-around plan that covers some co-payments, } \\
\text { deductibles, and services not covered under traditional } \\
\text { Medicare. Beneficiaries are given financial incentives to use } \\
\text { HMO providers but are not restricted to the HMO's panel }\end{array}$ \\
\hline Other Non-HMO Plans & $\begin{array}{l}\text { This category primarily includes enrollees in flexcare plans, } \\
\text { self-insured Medicare plans, managed indemnity, indemnity, } \\
\text { exclusive provider organizations (EPOs), and out-of-area plans }\end{array}$ \\
\hline
\end{tabular}


Exhibit 2: InterStudy Health Plans by Ownership Type in the DC-MD-VA Market, 2001

\begin{tabular}{|l|l|l|l|}
\hline $\begin{array}{l}\text { National For-Profit } \\
\text { Plans }\end{array}$ & $\begin{array}{l}\text { Virginia } \\
\text { Blue Cross Blue } \\
\text { Shield }\end{array}$ & Independent Plans & CareFirst Plans \\
\hline $\begin{array}{l}\text { United Healthcare of } \\
\text { Mid-Atlantic }\end{array}$ & Healthkeepers & $\begin{array}{l}\text { Kaiser of the Mid- } \\
\text { Atlantic }\end{array}$ & $\begin{array}{l}\text { FreeState } \\
\text { HealthPlan }\end{array}$ \\
\hline $\begin{array}{l}\text { Aetna U.S. Healthcare } \\
\text { MD) }\end{array}$ & $\begin{array}{l}\text { Peninsula Health } \\
\text { Care }\end{array}$ & $\begin{array}{l}\text { GW University } \\
\text { Health Plan }\end{array}$ & $\begin{array}{l}\text { Delmarva Health } \\
\text { Plan }\end{array}$ \\
\hline Prudential/Aetna (VA) & $\begin{array}{l}\text { Priority Health } \\
\text { Care }\end{array}$ & M.D. - IPA & $\begin{array}{l}\text { CareFirst } \\
\text { BlueChoice }\end{array}$ \\
\hline $\begin{array}{l}\text { CIGNA Healthcare of } \\
\text { VA }\end{array}$ & & $\begin{array}{l}\text { OPTIMA Health } \\
\text { Plan }\end{array}$ & PHN-HMO \\
\hline $\begin{array}{l}\text { Southern Health } \\
\text { Services }\end{array}$ & $\begin{array}{l}\text { QualChoice of } \\
\text { Virginia }\end{array}$ & \\
\hline $\begin{array}{l}\text { CIGNA Healthcare of } \\
\text { Mid-Atlantic }\end{array}$ & & Optimum Choice & \\
\hline Prudential/Aetna (MD) & & Carilion Health Plans & \\
\hline $\begin{array}{l}\text { United Healthcare of } \\
\text { VA }\end{array}$ & & $\begin{array}{l}\text { D.C. Chartered } \\
\text { Health Plans }\end{array}$ & \\
\hline AMERIGROUP (MD) & & $\begin{array}{l}\text { Piedmont } \\
\text { Community } \\
\text { HealthCare }\end{array}$ & \\
\hline & & $\begin{array}{l}\text { Advantage } \\
\text { Healthplan }\end{array}$ & Capital Community \\
Health Plan & \\
\hline & & & \\
\hline
\end{tabular}


Exhibit 3: National For-Profit Plans in the InterStudy Database

\begin{tabular}{|l|r|r|r|}
\hline Plan Name & $\begin{array}{r}\text { \# plans } \\
2001\end{array}$ & $\begin{array}{r}\text { HMO } \\
\text { Enrollment } \\
1999\end{array}$ & $\begin{array}{r}\text { HMO } \\
\text { Enrollment } \\
2001\end{array}$ \\
\hline CIGNA & 31 & 6920006 & 6562433 \\
\hline Maxicare & 2 & 517271 & 339455 \\
\hline Prudential** & 0 & 5245116 & - \\
\hline United & 44 & 8496515 & 14888720 \\
\hline Aetna & 57 & 6545789 & 8673581 \\
\hline Humana & 9 & 2966927 & 2189000 \\
\hline Mutual of Omaha & 2 & 230866 & 698522 \\
\hline Coventry & 16 & 1435538 & 2313007 \\
\hline Amerihealth & 4 & 377927 & 314006 \\
\hline Amerigroup & 4 & 113814 & 418604 \\
\hline Foundation Health Plans & 8 & 4187941 & 4572801 \\
\hline Pacificare & 8 & 3942926 & 3591033 \\
\hline Great Western & 15 & 1003952 & 1210757 \\
\hline
\end{tabular}

* Maxicare terminated two health plans between 1999 and 2000 **Prudential Health was bought by Aetna Health Plans 


\section{Exhibit 4: Definitions of HEDIS Quality Measures}

\begin{tabular}{|c|c|}
\hline $\begin{array}{l}\text { Adolescent } \\
\text { Immunization Rates }\end{array}$ & $\begin{array}{l}\text { Estimates the percentage of adolescent health plan members } \\
\text { that have been verified to have received all required doses of } \\
\text { several vaccines by their } 13^{\text {th }} \text { birthday. }\end{array}$ \\
\hline $\begin{array}{l}\text { Advising Smokers to } \\
\text { Quit Rates }\end{array}$ & $\begin{array}{l}\text { Measures the percentage of eligible health plan members who } \\
\text { were advised to quit smoking during a visit with a physician } \\
\text { during the measurement year. }\end{array}$ \\
\hline $\begin{array}{l}\text { Use of Appropriate } \\
\text { Medications for } \\
\text { People with Asthma }\end{array}$ & $\begin{array}{l}\text { Evaluates whether health plan members who are suffering from } \\
\text { persistent asthma are being prescribed medications deemed } \\
\text { acceptable by the National Heart, Lung and Blood institute as } \\
\text { primary therapy for long term control of asthma }\end{array}$ \\
\hline $\begin{array}{l}\text { Beta Blocker } \\
\text { Treatment After a } \\
\text { Heart Attack }\end{array}$ & $\begin{array}{l}\text { Estimates the percentage of members' age } 35 \text { and older } \\
\text { hospitalized and discharged from the hospital after surviving a } \\
\text { heart attack (defined as an acute myocardial infarction or AMI), } \\
\text { who received a prescription for a beta blocker. }\end{array}$ \\
\hline $\begin{array}{l}\text { Breast Cancer } \\
\text { Screening Rates }\end{array}$ & $\begin{array}{l}\text { Estimates the percentage of women aged } 52 \text { through } 69 \text { years } \\
\text { enrolled in a health plan who had a mammogram during the } \\
\text { measurement year or the year prior to the measurement year. }\end{array}$ \\
\hline $\begin{array}{l}\text { Cervical Cancer } \\
\text { Screening Rates }\end{array}$ & $\begin{array}{l}\text { Estimates the percentage of women age } 21-64 \text { who were } \\
\text { enrolled in a health plan and who had on Papanicolau (Pap) test } \\
\text { during measurement year or the two years prior. }\end{array}$ \\
\hline $\begin{array}{l}\text { Childhood } \\
\text { Immunization Rates }\end{array}$ & $\begin{array}{l}\text { Estimates the percentage of children who were enrolled in } \\
\text { managed care plans and turned two years old during the } \\
\text { measurement year, who had received vaccinations: (1) four } \\
\text { dosed of DTP or DtaP (diptheria-tetanus; (2) three doses of } \\
\text { OPV or IPV (polio); (3) one dose of MMR (measles-mumps- } \\
\text { rubella); (4) two doses of Hib (Haemophilus influenza), (5) } \\
\text { three doses of Hepatitis B, (6) one dose of VZV (chicken pox). }\end{array}$ \\
\hline $\begin{array}{l}\text { Chlamydia Screening } \\
\text { Rates }\end{array}$ & $\begin{array}{l}\text { Estimates the percentage of sexually active female plan member } \\
\text { who had ate least one test for chlamydia during the } \\
\text { measurement year. The measure is collected separately for } \\
\text { women aged } 16-20 \text { and } 21-26 \text {. }\end{array}$ \\
\hline $\begin{array}{l}\text { Comprehensive } \\
\text { Diabetes Care }\end{array}$ & $\begin{array}{l}\text { Measure set includes several important features of effective, } \\
\text { multphasic management of diabetes and it's complications. The } \\
\text { measure estimated the percentage of health plan member with } \\
\text { Type } 1 \text { and Type } 2 \text { diabetes who were } 18-75 \text { years old and, } \\
\text { during the measurement year: (1) had a Hemoglobin A1c } \\
\text { (HbA1c) test; (2) had poorly controlled HbAlc (level greater } \\
\text { that } 9.5 \%) \text {; (3) had a serum cholesterol level (LDL-C) } \\
\text { screening; (4) had their cholesterol level (LDL-C) controlled to } \\
\text { less than } 130 \mathrm{mg} / \mathrm{dl} \text {; (5) had an eye exam; and (6) had a } \\
\text { screening for kidney disease. }\end{array}$ \\
\hline $\begin{array}{l}\text { Follow-up After } \\
\text { Mental Illness, 7-Day } \\
\text { and 30-Day Rates }\end{array}$ & $\begin{array}{l}\text { Indicates the percentage of health plan members age six and } \\
\text { older who received inpatient treatment for a mental health } \\
\text { disorder and had an ambulatory or day/night follow-up visit }\end{array}$ \\
\hline
\end{tabular}




\begin{tabular}{|l|l|}
\hline & after being discharged. \\
\hline $\begin{array}{l}\text { Prenatal and } \\
\text { Postpartum Care Rates }\end{array}$ & Measures timeliness of prenatal care and postpartum care. \\
\hline
\end{tabular}




\section{Exhibit 4: Definitions of CAHPs Quality Measures}

\begin{tabular}{|c|c|}
\hline Getting Care Quickly & $\begin{array}{l}\text { Measures timeliness of services received form health care } \\
\text { providers in the last } 12 \text { months. }\end{array}$ \\
\hline Claims Processing & $\begin{array}{l}\text { Measures managed care enrollees' experiences with sending in } \\
\text { claims to their health plans in the last } 12 \text { months. }\end{array}$ \\
\hline Customer Service & $\begin{array}{l}\text { Measures how much of a problem it was for enrollees in } \\
\text { managed care plans to get information and to fill out paperwork } \\
\text { in the last } 12 \text { months. }\end{array}$ \\
\hline $\begin{array}{l}\text { How Well Doctors } \\
\text { Communicate }\end{array}$ & $\begin{array}{l}\text { Measures the experiences consumers had while seeing a doctor } \\
\text { or health care provider in the last } 12 \text { months. }\end{array}$ \\
\hline Getting Needed Care & $\begin{array}{l}\text { Is a "composite" measure, made up of several questions related } \\
\text { to consumers' experiences in attempting to get care from } \\
\text { doctors and specialists. }\end{array}$ \\
\hline $\begin{array}{l}\text { Courtesy of Office } \\
\text { Staff }\end{array}$ & $\begin{array}{l}\text { Measures managed care enrollees' perception of quality of } \\
\text { customer service when interacting with staff in their doctors' } \\
\text { offices and clinics in the last } 12 \text { months. }\end{array}$ \\
\hline $\begin{array}{l}\text { Overall Rating of } \\
\text { Doctor }\end{array}$ & $\begin{array}{l}\text { Respondents were asked to rate their personal doctor or nurse } \\
\text { with ' } 0 \text { ' equaling "worst personal doctor or nurse possible" and } \\
\text { ' } 10 \text { ' equaling 'best personal doctor or nurse possible. }\end{array}$ \\
\hline $\begin{array}{l}\text { Overall Rating of } \\
\text { Specialist }\end{array}$ & $\begin{array}{l}\text { Respondents who had seen a specialist physician in the last } \\
12 \text { months were asked to rate their specialist with ' } 0 \text { ' equaling } \\
\text { "worst specialist possible" and ' } 10 \text { ' equaling "best specialist } \\
\text { possible. }\end{array}$ \\
\hline $\begin{array}{l}\text { Overall Rating of } \\
\text { Health Plan }\end{array}$ & $\begin{array}{l}\text { Respondents were asked to rate their health plan with ' } 0 \text { ' } \\
\text { equaling "worst health plan possible" and ' } 10 \text { ' equaling 'best } \\
\text { health plan possible. }\end{array}$ \\
\hline $\begin{array}{l}\text { Overall Rating of } \\
\text { Health Care }\end{array}$ & $\begin{array}{l}\text { Respondents were asked to rate the quality of the health care } \\
\text { they received in the last } 12 \text { months, with ' } 0 \text { ' equaling "worst } \\
\text { health care possible" and ' } 10 \text { ' equaling 'best health care } \\
\text { possible. }\end{array}$ \\
\hline
\end{tabular}

